Research paper

\title{
First record of Permo-Triassic palynomorphs of the N'Condédzi sub-basin, Moatize-Minjova Coal Basin, Karoo Supergroup, Mozambique
}

\author{
Francesca Galasso ${ }^{\mathrm{a}, \mathrm{b}, 1}$, Zélia Pereira $^{\mathrm{c}, *}$, Paulo Fernandes $^{\mathrm{b}}$, Amalia Spina ${ }^{\mathrm{a}}$, João Marques ${ }^{\mathrm{d}}$ \\ a Department of Physics and Geology, University of Perugia, Via Pascoli, 06123 Perugia, Italy \\ b Centro de Investigação Marinha e Ambiental (CIMA), Universidade do Algarve, Campus de Gambelas, 8005-139 Faro, Portugal \\ c Laboratório Nacional de Energia e Geologia (LNEG), Rua da Amieira, Apartado 1089, 4466-901 S. Mamede Infesta, Portugal \\ d Gondwana Empreendimentos e Consultorias, Limitada, Rua B, no. 233, Bairro da COOP, Caixa Postal 832, Maputo, Mozambique
}

\section{A R T I C L E I N F O}

\section{Keywords:}

Spores

Pollen

Lopingian

Induan-Olenekian

Carnian

Karoo Palaeogeography

\begin{abstract}
A B S T R A C T
Permian-Triassic ages have been identified for the first time in the Karoo Supergroup of the N'Condédzi sub-basin, Moatize-Minjova Coal Basin, Mozambique. This transition was identified in a coal exploration borehole that penetrated the Matinde and Cádzi formations. The top of the Matinde Formation is dated latest Permian (Lopingian), and the Cádzi Formation is attributed to Triassic based on palynostratigraphy. The Lopingian age is established by the identification of three palyno-assemblages: Assemblage L1 based on the first occurrence (FO) of Guttulapollenites pollen, Assemblage L2 is marked by the FO of Thymospora pseudothiessenii, and Assemblage L3 is defined by the FO of Osmundacidites senectus. Triassic palynomorphs were identified for the first time in Mozambique (Karoo basins). The data allowed the identification of three assemblages: Assemblage T1 defined by the FO of Densoisporites nejburgii of Induan age, Assemblage T2 is marked by the FO of Platysaccus queenslandi and assigned to the Olenekian age, and Assemblage T3 is defined by the FO of Samaropollenites speciosus and Enzonalasporites vigens, indicating a Carnian age. No Middle Triassic rocks were identified, and the early Triassic sediments are overlain by sedimentary rocks of Carnian age, a hiatus that may correspond to an important tectonic event with uplift and erosion. This tectonic event is also suggested by the occurrence of common reworked Permian palynomorphs in the Carnian sedimentary rocks. These new data constrain the age of the Karoo Supergroup formations of Mozambique and contribute to improve the palaeoecological, palaeoclimatic evolution, and the palaeogeographic position of the Karoo Mozambique basins within the Gondwana supercontinent.
\end{abstract}

(c) 2019 Elsevier Masson SAS. All rights reserved.

\section{Introduction}

In the last decade, the increase in the exploration and exploitation of coal in the Mozambique Karoo basins is documented especially in the region surrounding Tete city, in the Province of Tete (Fig. 1). This growth was due, in part, to an effort initiated several years earlier by the Mozambican Geological Survey (Direcção Nacional de Geologia) that in partnership with other countries geological surveys revised the geology of the entire country, leading to the publication of a new series of geological maps (GTK Consortium, 2006; Norconsult Consortium, 2007). Regarding the geology of the

\footnotetext{
* Corresponding author.

E-mail address: zelia.pereira@lneg.pt (Z. Pereira).

${ }^{1}$ Currently at University of Zurich.
}

Karoo sequences, new lithostratigraphic units were proposed (GTK Consortium, 2006; Paulino et al., 2010). However, these new stratigraphic studies were not complemented, from the beginning, with scientific works directed to exploration decisions and associated to reduce risks related to this activity. For example, until the present, very few paleontological, palynological, and palaeoecological studies that ascertain the age and the depositional conditions of the coal-bearing basins have been published. Specifically, regarding coal exploration, this significant mapping effort led to the definition and concession of new areas for exploration that were followed by intensive drilling campaigns. Thus, boreholes made recently available by several exploration companies are supporting the completion of numerous studies in the Moatize-Minjova Coal Basin (MMCB) (Fig. 1) including palynostratigraphy (Pereira et al., 2014; Lopes et al., 2014; Pereira et al., 2016; Götz et al., 2018), thermal history (Fernandes et al., 2015; Galasso et al., 2019), Permian climatic 


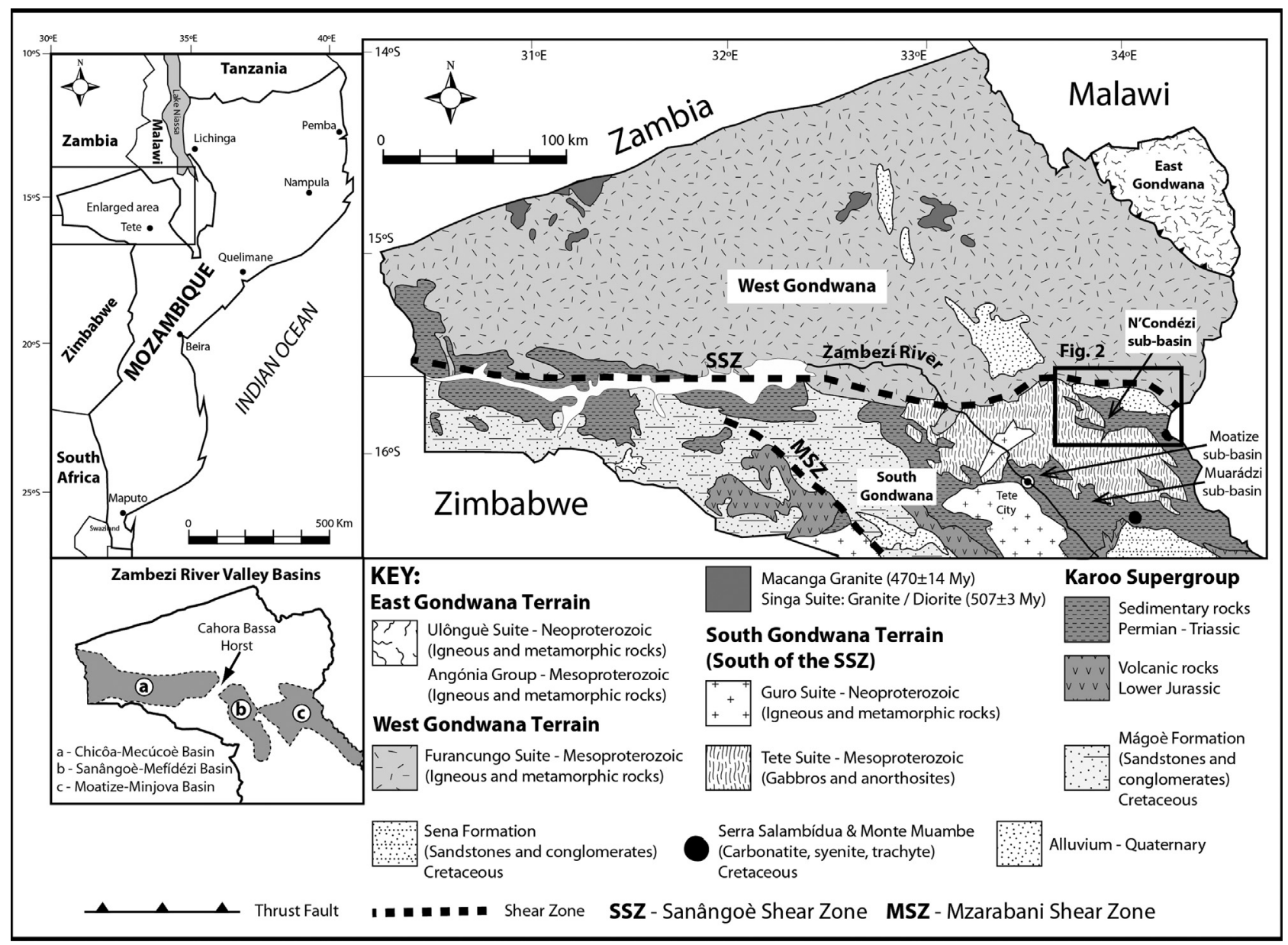

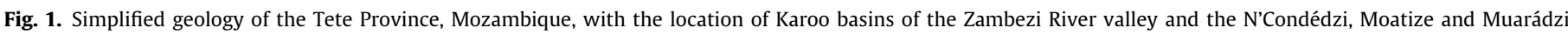
sub-basins.

Adapted from Geological Map of Mozambique, Direcção Nacional de Geologia, Maputo (2006).

changes (Götz et al., 2017), the tectonostratigraphy (Bicca et al., 2017) and sediment provenance (Bicca et al., 2018). The present work deals with the palynostratigraphy of the formations positioned at the top of the Karoo Supergroup stratigraphic succession of Mozambique, aiming to date these formations, and to contribute to a better understanding and characterise the palaeoecological and palaeoclimatic features recorded in these deposits. With this study, we will aim to improve the knowledge on the palaeogeographic position of these basins within the Gondwana supercontinent and ultimately contribute to coal seam identification and correlation required in future coal exploration programmes.

\section{Geological setting of the N'Condédzi sub-basin}

The N'Condédzi sub-basin is one of the several sub-basins that form the main MMCB. In turn, the MMCB is one of the three main basins located along the Zambezi river valley in the province of Tete (Lächelt, 2004; GTK Consortium, 2006) (Fig. 1). The MMCB is the best studied of all the Karoo basins in Mozambique, mainly due to the presence of abundant coal seams, which are currently being exploited in two mines (Vale Moatize and ICLV Benga mines). The development of Karoo basins in the province of Tete is related to the brittle reactivation of high strain shear zone (e.g., the Sanângoé and Mzarabani shear zones) of the Zambezi Belt, formed during the Pan-African Orogeny (620-530 Ma) (Carvalho, 1977; Afonso, 1984; Pinna et al., 1993; Jamal, 2005; GTK Consortium, 2006; Norconsult Consortium, 2007; Grantham et al., 2008; Viola et al., 2008).
The stratigraphic succession of the MMCB consists of four clastic formations, which are from base to top, Vúzi, Moatize, Matinde, and Cádzi formations. From these lithostratigraphic units, the Moatize Formation in its type area (around Moatize town) has six main coal seams interbedded with sandstones and mudstones. Parts of these stratigraphic units were recognized in the N'Condèdzi sub-basin (Lakshminarayana, 2015), whose general geology is described below; however, a detailed description of the geology and lithostratigraphy of the MMCB can be found in publications such as Lächelt (2004), GTK Consortium (2006), Vasconcelos (2013), Fernandes et al. (2015) and Pereira et al. (2016).

A comprehensive work on the N'Condédzi sub-basin was published by Lakshminarayana (2015). Although this work is mainly focused on several aspects of coal geology and exploration, it also provides new information about the stratigraphic succession in this area. The N'Condédzi sub-basin is located $c a .50 \mathrm{~km}$ to NE of the Tete city (Fig. 1). Its northern boundary corresponds to the Mwanza Fault (Fig. 2), a brittle structure formed by the reactivation of the Sanângoè Shear Zone (SSZ) during the early(?) Permian, and related to the initial tectonic phases of this sub-basin development. The Mwanza Fault is a prominent geomorphologic feature at the northern boundary of this sub-basin, separating the granites and gneisses of the Mesoproterozoic Furancungo Suite and the flat region of the hanging wall fault block that corresponds to the Karoo sedimentary rocks (Fig. 2). According to Lakshminarayana (2015), the throw of the Mwanza Fault is more than $700 \mathrm{~m}$ towards the south, but Galasso et al. (2019) estimates that the throw of 


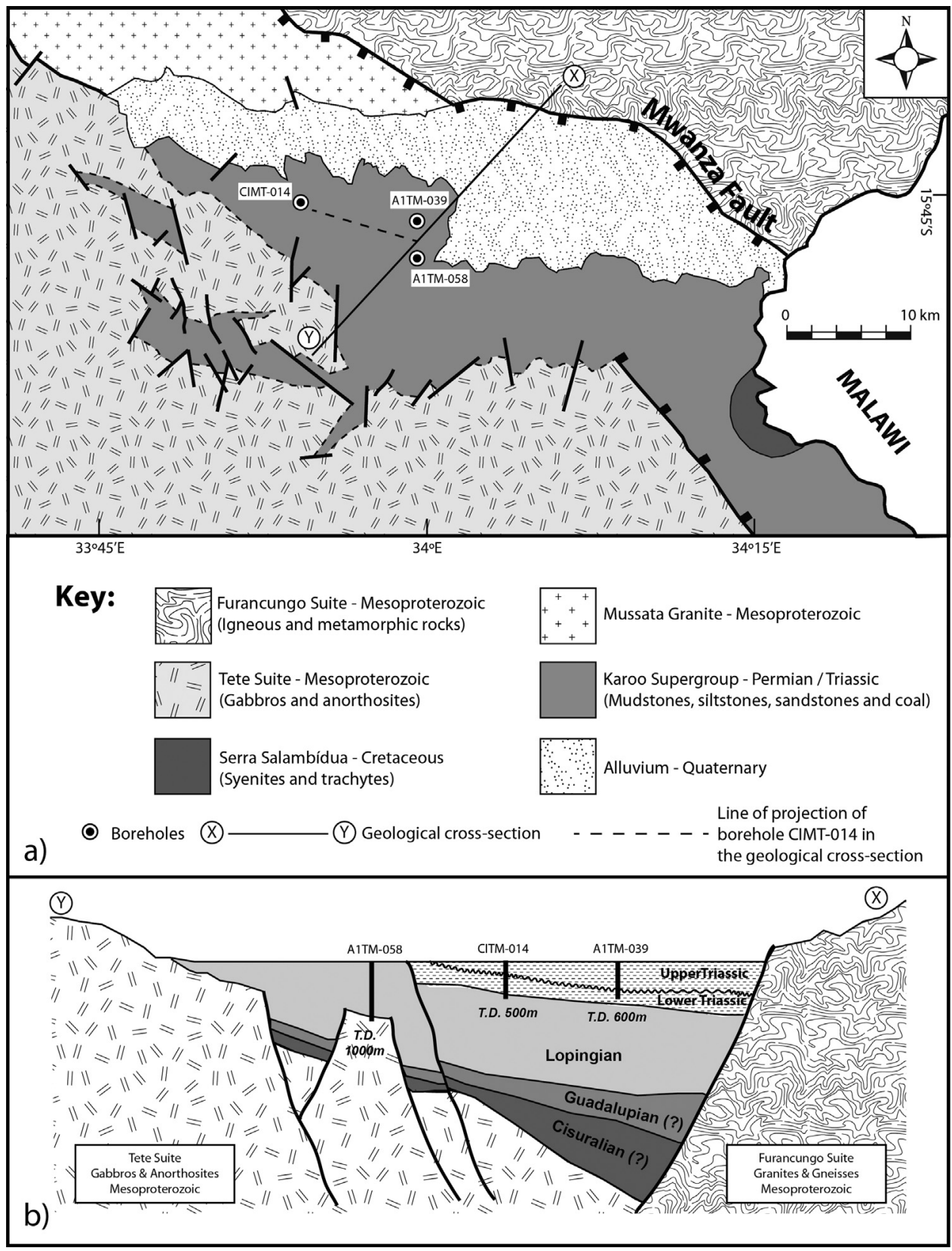

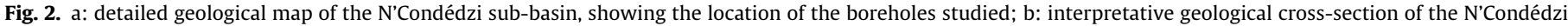

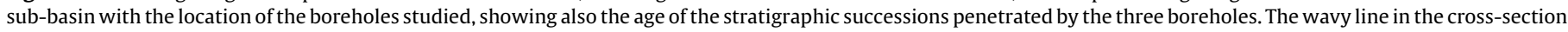
corresponds to the hiatus between the lower and upper Triassic rocks. Geological cross-section not at scale.

Adapted from Geological Map of Mozambique, Sheet No. 1533/1534, Cazula/Zóbuè, Geological Series 1/250,000, Direç̧ão Nacional de Geologia, Maputo (2006).

this fault is more than $1000 \mathrm{~m}$ towards the same direction, due to the presence of a combined Lopingian to Middle Triassic succession with a thickness of $c a .1500 \mathrm{~m}$. In the southern margin of this sub-basin, Karoo sedimentary rocks rest either unconformably over the Mesoproterozoic gabbros-anorthosites of the Tete Suite or are faulted against the later lithologies (Fig. 2). Different ages of the Karoo sedimentary rocks positioned immediately above the crystalline basement rocks, located in different positions of this basin (Galasso et al., 2019 and in present work), suggest that the Karoo sediments progressively overstepped the gentle tilted basement rocks towards South-Southwest (today's coordinates).

According to Lakshminarayana (2015), the stratigraphic succession of the N'Condédzi sub-basin starts, at the base, by the Vúzi Formation, which consists of clast to matrix-supported conglomerates and sandstones arranged into fining-upward cycles deposited in periglacial environments. The thickness of this formation varies from 60 to $140 \mathrm{~m}$. The Vúzi Formation passes upward to the 'Transitional Assemblage', a new informal lithostratigraphic unit defined by Lakshminarayana (2015). The latter unit consists of conglomerates, sandstones, mudstones, and cm-thick coal beds organized vertically into several fining-upward cycles, each cycle with a thickness of 3 to $5 \mathrm{~m}$, in an overall thickness of $c a .70 \mathrm{~m}$. This informal unit was deposited in the proximal areas of a major alluvial fan, characterise by plain-coal swamps in the distal parts of the fan. Above this unit, lays conformably the Moatize Formation, which is divided into two different lithofacies groups: a dominant sandstone lithofacies, consisting of sandstones interbedded with siltstones and mudstones, and the coal-carbonaceous mudstones lithofacies (Lakshminarayana, 2015). The latter consists of cyclic coal beds interbedded with carbonaceous mudstones and 

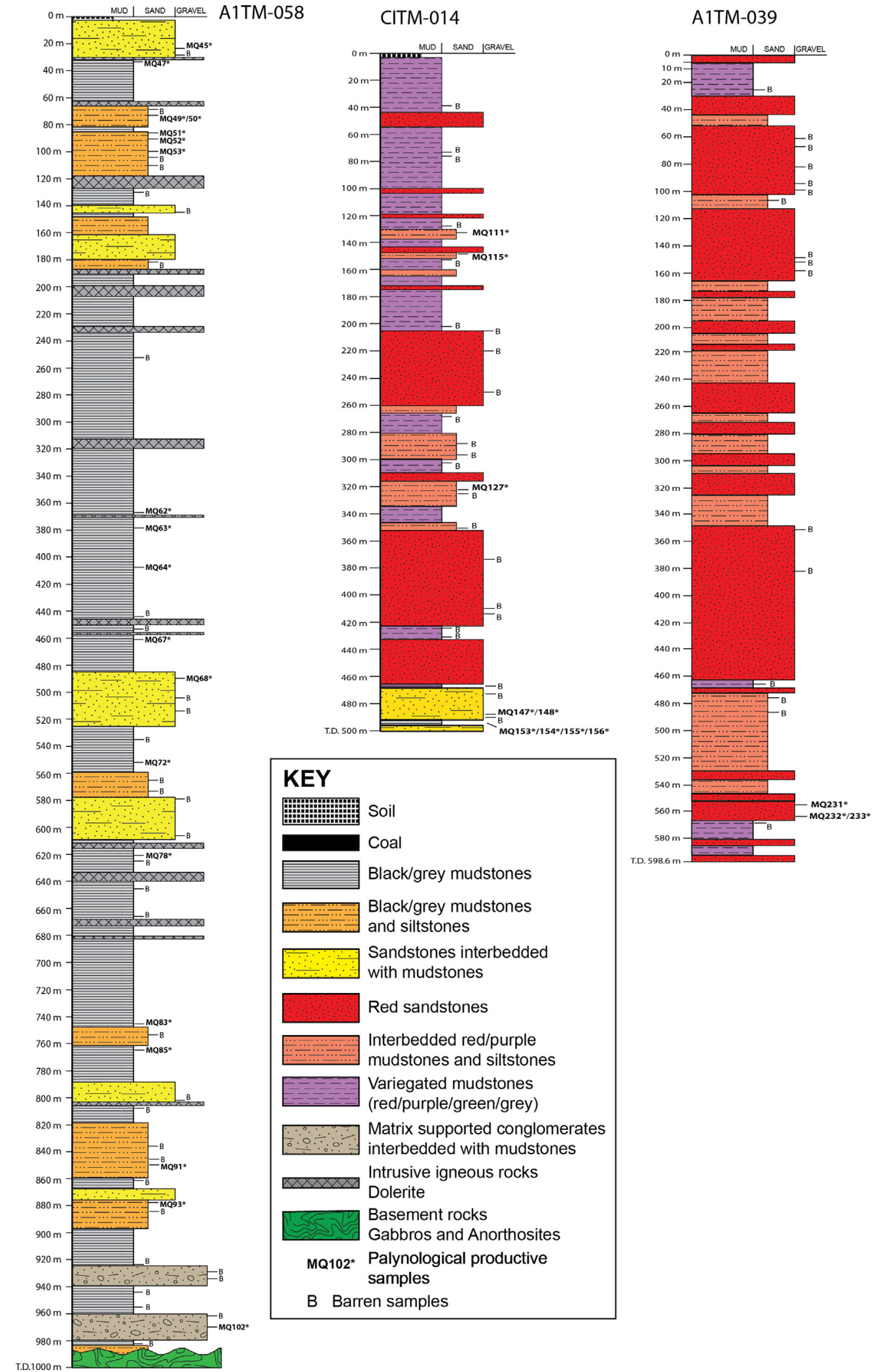

\begin{tabular}{|c|c|}
\hline & Black/grey mudstones \\
\hline$\ldots \cdots \cdots \cdots$ & $\begin{array}{l}\text { Black/grey mudstones } \\
\text { and siltstones }\end{array}$ \\
\hline$\because \because \because$ & $\begin{array}{l}\text { Sandstones interbedded } \\
\text { with mudstones }\end{array}$ \\
\hline & Red sandstones \\
\hline & $\begin{array}{l}\text { Interbedded red/purple } \\
\text { mudstones and siltstones }\end{array}$ \\
\hline & $\begin{array}{l}\text { Variegated mudstones } \\
\text { (red/purple/green/grey) }\end{array}$ \\
\hline$\because \because$ & $\begin{array}{l}\text { Matrix supported conglomerates } \\
\text { interbedded with mudstones }\end{array}$ \\
\hline $8 \times 8 \times$ & $\begin{array}{l}\text { Intrusive igneous rocks } \\
\text { Dolerite }\end{array}$ \\
\hline & $\begin{array}{l}\text { Basement rocks } \\
\text { Gabbros and Anorthosites }\end{array}$ \\
\hline MQ102* & $\begin{array}{l}\text { Palynological productive } \\
\text { samples }\end{array}$ \\
\hline B Barr & ren samples \\
\hline
\end{tabular}

Fig. 3. Lithological logs of boreholes A1TM-058, CIMT-014 and A1TM-039 with the position of the studied palynological samples.

siltstones, comprising the so-called barcode coal seams, constituting almost two-thirds of the overall thickness of the Moatize Formation. The thickness of Moatize Formation is more than $400 \mathrm{~m}$ in this sub-basin. The main Coal Seams or 'Carbonaceous Complexes' of the Moatize Formation, defined in the type area of the Moatize
(Benga) sub-basin, are recognized in the N'Condédzi sub-basin (Lakshminarayana, 2015). There are, however, some differences between the stratigraphy of the two sub-basins: in the N'Condédzi sub-basin, the Sousa Pinto Coal Seam occurs within the 'Transitional Assemblage', and not at the base of the Moatize Formation; the 


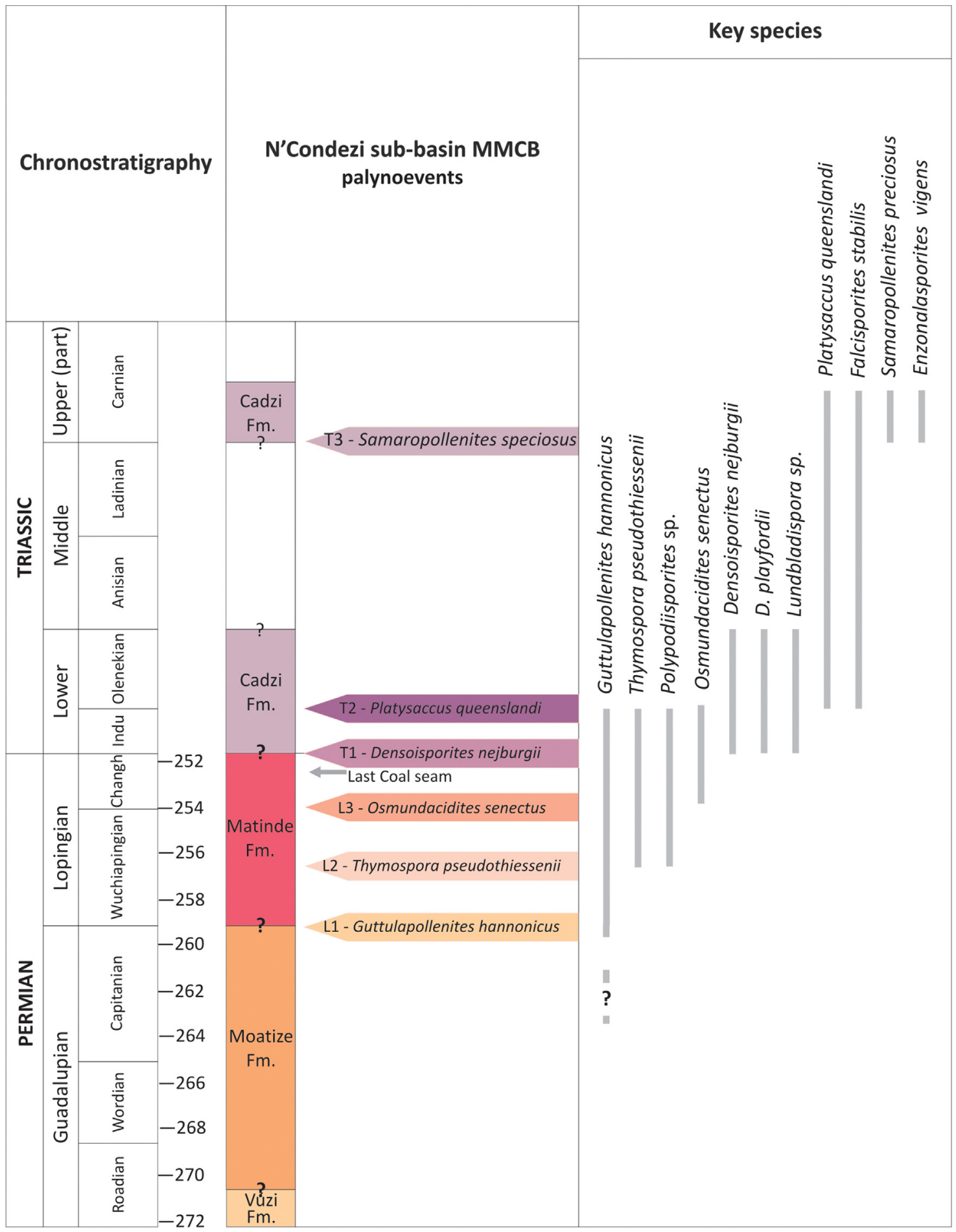

Fig. 4. Main palynological events and key species recovered in the N'Condédzi sub-basin, Moatize-Minjova Basin, Mozambique.

Grande Falésia and André Coal Seams are better developed in the N'Condédzi sub-basin, especially the Grande Falésia whose thickness varies between 110 and $250 \mathrm{~m}$, in clear contrast with the $12 \mathrm{~m}$ thickness recognized for this coal seam in the Moatize sub-basin (Lächelt, 2004).

The Matinde Formation conformably overlays the Moatize Formation and comprises conglomerates and thick beds of coarseto-medium-grained sandstones, with rare interbedded mudstones. The thickness of the Matinde Formation in this sub-basin is unknown. Palaeocurrents measured in cross-bedded sandstones of the Matinde Formation show a predominant ESE direction
(Lakshminarayana, 2015). The stratigraphic succession terminates with the Cádzi Formation that consists of conglomerates, red coarse-to-medium-grained sandstones, interbedded with red to green mudstones. Dolerite sills related to the Lower Jurassic KarooFerrar Large Igneous Province (Duncan et al., 1997) are found intruded, especially in the Moatize Formation.

Due to the absence of any biostratigraphic information, Lakshminarayana (2015) correlated the Vúzi Formation with the late Pennsylvanian-early Cisuralian Dwyka Group of the Main Karoo Basin of South Africa and the Moatize and Matinde formations with the Cisuralian-early Lopingian Ecca Group. 


\section{Material and methods}

Ninety-nine core samples were collected for a palynostratigraphic study from three coal exploration boreholes (A1TM-058, CIMT-014 and A1TM-039) drilled in the N'Condédzi sub-basin (Figs. 2 and 3). Thirty-one samples proved productive containing moderately preserved and diversified palynomorphs. A minimum of 200 palynomorphs were counted per slide (Tables $1-3$ ). The following adjectives were used to describe the different palynomorphs identified: Abundant (>50\%), Common (10-50\%), and Rare (<10\%).

The palynological samples were treated with standard palynological laboratory procedures to extract and concentrate the organic matter. The organic residues were oxidized using fuming nitric acid for approximately 1 minute (Wood et al., 1996; Riding and Warny, 2008). The slides were examined under transmitted light, with a BX40 Olympus microscope equipped with an Olympus C5050 digital camera and Qualitative spore fluorescence colours was undertaken in the University of the Algarve using an Olympus BX51 microscope equipped with a metal halide lamp fluorescence unit (XCite Series 120Q) and with a violet and Blue +12 filter block that generates a wavelength band of 390-490 nm. This system was allowed to stabilize for 5 minutes before any observation of the fluorescence of palynomorphs was attempted. All samples, residues and slides are held both in the University of the Algarve, Portugal, and in the Collection of the Geological Survey of Portugal, LNEG, S. Mamede de Infesta. Selected palynomorphs are illustrated in Plates 1-5.

\section{Borehole lithostratigraphic description}

\subsection{Borehole A1TM-058}

This borehole attained a total depth of $1000 \mathrm{~m}$ and penetrated, at its base, a $4 \mathrm{~m}$ sequence of basement rocks (gabbro-anorthosites) belonging to the Mesoproterozoic Tete Suite (Fig. 3). The basement rocks are unconformably overlain by an $8 \mathrm{~m}$ thick sequence consisting of red siltstones interbedded with red mudstones that pass upwards to black carbonaceous mudstones beds. The $980 \mathrm{~m}$ to $930 \mathrm{~m}$ depth interval consists of two sections of clast to matrixsupported conglomerates interbedded with black mudstones and black carbonaceous mudstones. The latter interval is followed by a succession of approximately $180 \mathrm{~m}$ thick of cyclic sandstones/siltstones beds interbedded with black mudstones. Most of the succession above $750 \mathrm{~m}$, and to $190 \mathrm{~m}$ depth, comprises black carbonaceous mudstones, black mudstones, siltstones and coal beds, with the coarser lithologies (sandstones) concentrated between $610 \mathrm{~m}$ to $490 \mathrm{~m}$ depth. This thick interval is also characterised by the occurrence of several intrusive dolerite sills. From $190 \mathrm{~m}$ depth to the top of the borehole, the succession consists of coarse- to medium-grained sandstones intercalated with siltstones, carbonaceous mudstones and thin coal beds.

\subsection{Borehole CIMT-014}

The borehole succession consists mainly of red clastic lithologies, which are in clear contrast with the succession of the previous borehole, denoting a marked change in the depositional and palaeoenvironmental settings. This borehole has a total depth of $500 \mathrm{~m}$ (Fig. 3), and the succession from total depth to ca. $489 \mathrm{~m}$ is dominated by intercalations of black carbonaceous mudstones, siltstones, and fine-grained sandstones beds. The interval from $484.5 \mathrm{~m}$ to $463 \mathrm{~m}$ depth consists of grey siltstones interbedded with fine-grained grey sandstones that are followed upwards by a $4.5 \mathrm{~m}$ thick bed of clast-supported conglomerates interbedded with two centimetric thick grey mudstones beds. From ca. $463 \mathrm{~m}$ to $350 \mathrm{~m}$ depth, there is a second prominent sandstone-dominated interval consisting of red to purple conglomerates, coarse- to mediumgrained sandstones interbedded with rare red-brown mudstones and siltstones. The succession between $350 \mathrm{~m}$ and $260 \mathrm{~m}$ depth consists of fine-grained lithologies, red mudstones and siltstones with few medium-grained sandstone beds. A prominent coarseto medium-grained sandstone section with rare grey mudstone lenses characterises the following $50 \mathrm{~m}$ interval, which ends at $210 \mathrm{~m}$ depth. Lastly, from $210 \mathrm{~m}$ depth to the top of the borehole, the succession is dominated by red-brown mudstones interbedded with thin beds of brown siltstones, medium-grained red-yellow sandstones and rare lenses of grey mudstones.

\subsection{Borehole A1TM-039}

As borehole CIMT-014, this borehole penetrated approximately $600 \mathrm{~m}$ of mainly red clastic sedimentary beds (Fig. 3). However, borehole A1TM-039 is richer in coarse-grained clastic sedimentary rocks than borehole CIMT-014. From total depth to ca. $564 \mathrm{~m}$ depth, the succession consists of grey-black mudstones interbedded with yellow buff medium-grained sandstones. From $564 \mathrm{~m}$ to $470 \mathrm{~m}$ depth, the succession consists of red-brown siltstones interbedded with red mudstone beds and few red sandstones levels. Following upwards, the interval from $470 \mathrm{~m}$ to $350 \mathrm{~m}$ depth is dominated by thick coarse- to medium-grained red-pink sandstone beds. Finally, from $350 \mathrm{~m}$ to the top of the borehole, the succession comprises thick conglomerate beds and coarse- to medium-grained sandstones that are intercalated with less common red-brown siltstones and mudstones beds.

\section{Palynological results}

The quantitative and qualitative distribution of the palynomorph assemblages presented is based on the relatively abundance of the taxa and on the FO of particular taxa. Three assemblages of Lopingian age (L1 to L3), also identified in the stratigraphic succession of the Muarádzi sub-basin of the MMCB (Pereira et al., 2019), and three assemblages assigned to the Triassic (T1 to T3) are described in this work (Tables 1-3). lows.

In stratigraphic order, the palynomorph assemblages are as fol-

\subsection{Assemblage L1}

This assemblage is characterised by a clear dominance of gymnosperms taeniate bisaccate pollen (Protohaploxypinus spp. and Striatopodocarpites spp.) and non-taeniate pollen (Alisporites spp.). Typical taxa are Alisporites spp. (A. plicatus, A. potoniei, A. ovatus), Protohaploxypinus spp. (e.g., P. amplus, P. diagonalis, P. goraiensis, P. hartii and P. limpidus) and Striatopodocarpites spp., as well as rare to common Cycadopites cymbatus, Lueckisporites virkkiae, Platysaccus sp. and Vittatina spp. Common to abundant Guttulapollenites hannonicus and Weylandites lucifer, as well as rare to common monossacate pollen assigned to the taxa Cannanoropollis sp. are also present. Spores are rare to common and include Apiculatisporis sp., Baculatisporites sp., Brevitriletes cornutus, Brevitriletes sp., Calamospora spp., Cyclogranisporites sp., Fabasporites sp., Horriditriletes spp., Laevigatisporites spp., Leiotriletes sp. and rare Microbaculispora sp., Procoronaspora spinosa, Verrucosisporites sp. and Verrucosisporites andersonii (Table 1 ).

Occurrence: Borehole A1TM-058, sample interval MQ102 to MQ85. 

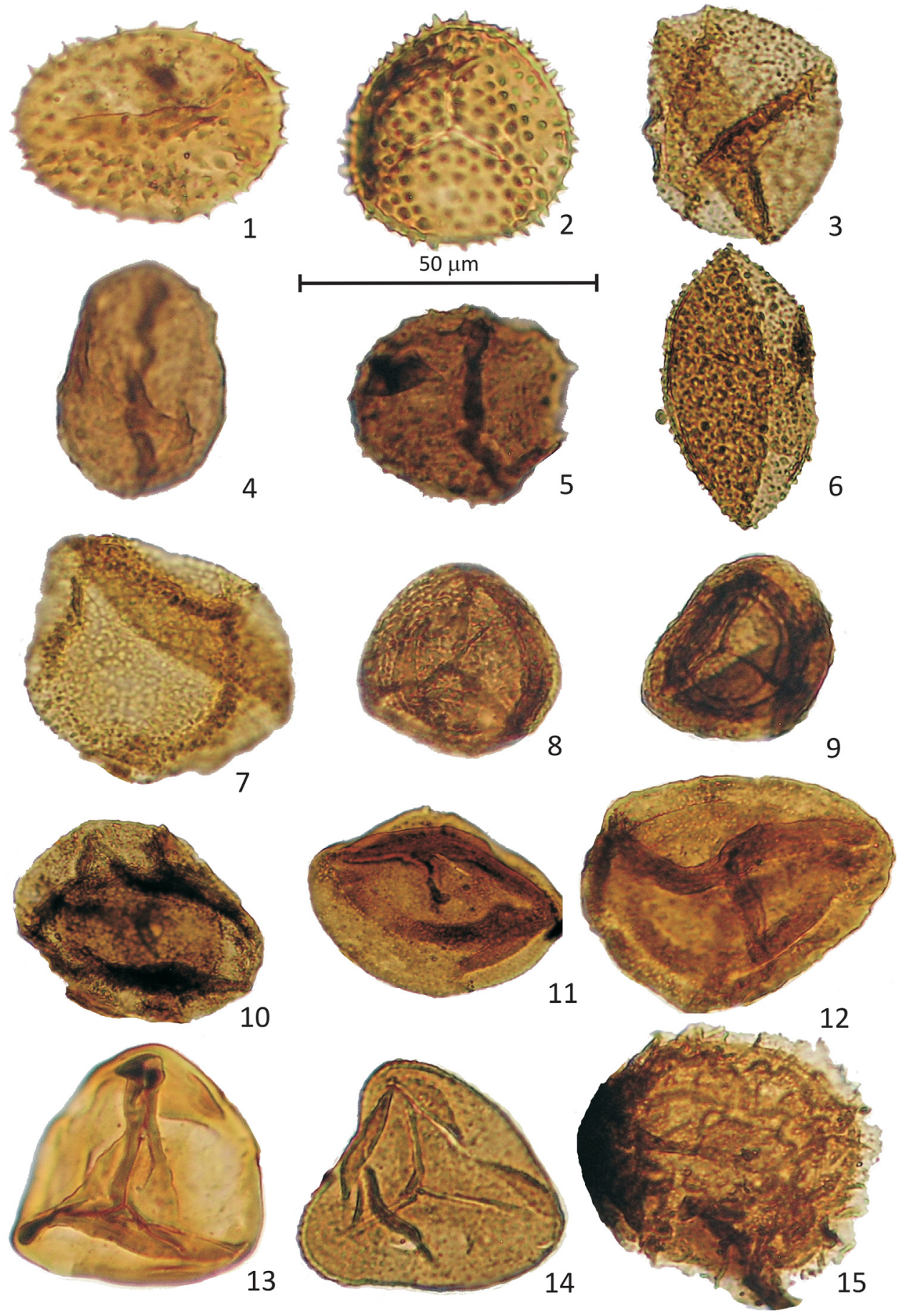

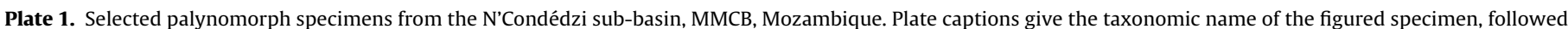

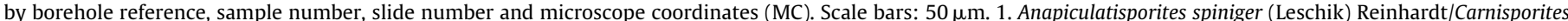

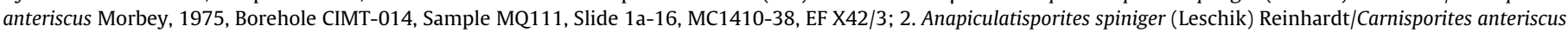

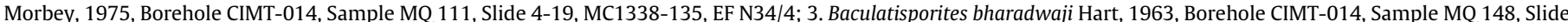

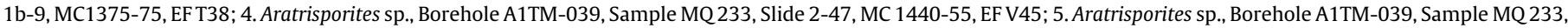

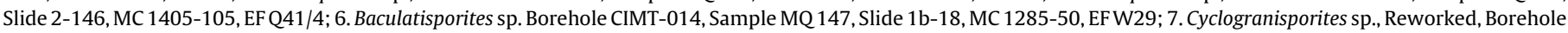

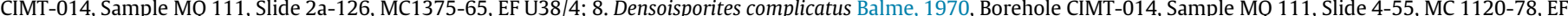

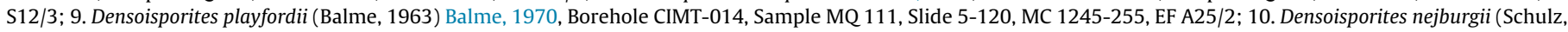

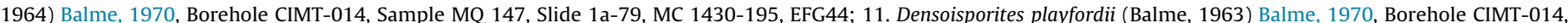

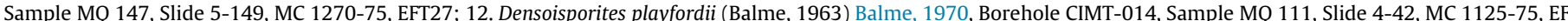

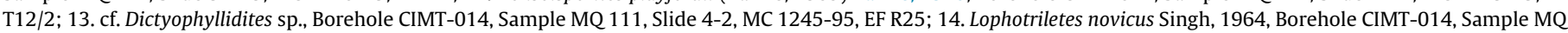
147, Slide 5-3, MC 1510-65, EF R25/4; 15. Kraeuselisporites sp., Borehole CIMT-014, Sample MQ 111, Slide 2b-34, MC 1310-140, EF M31/4. 

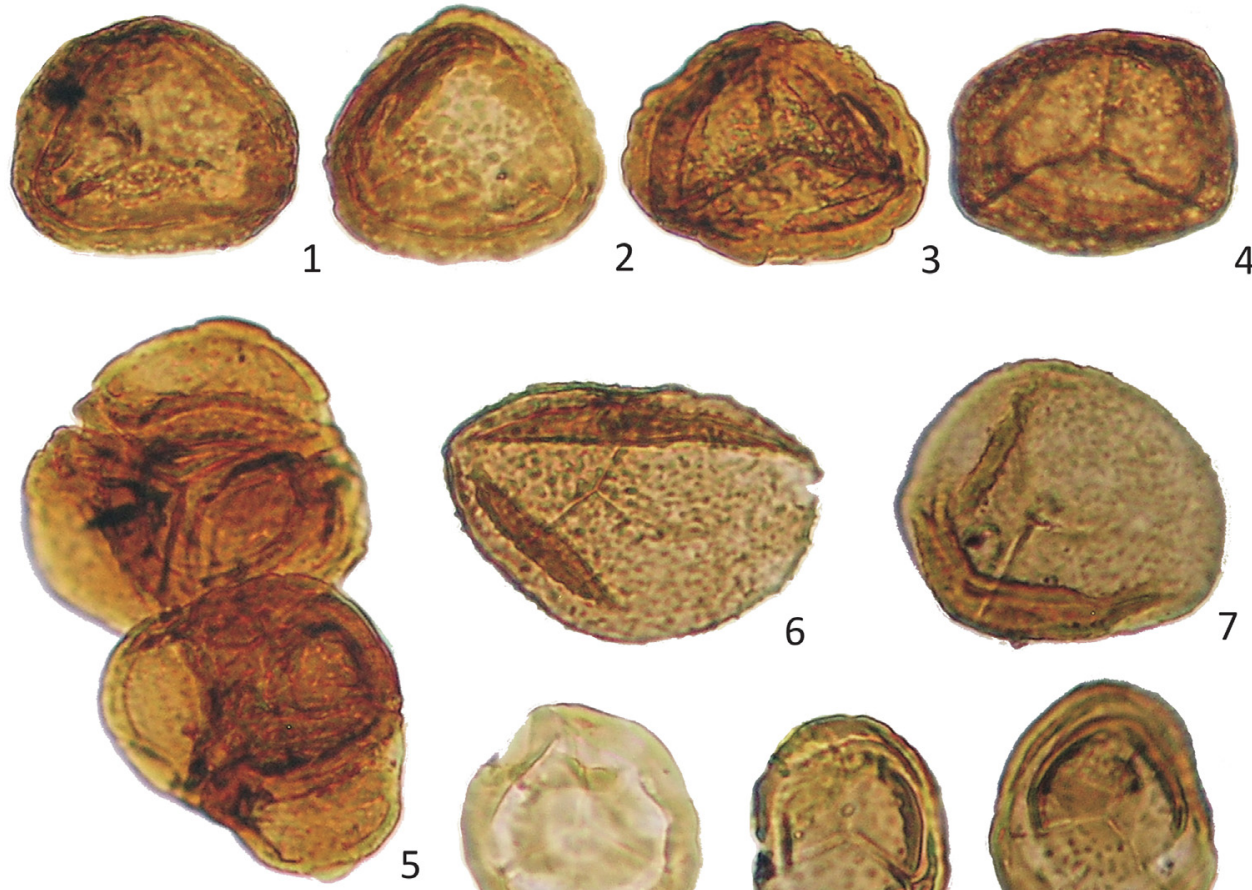

5
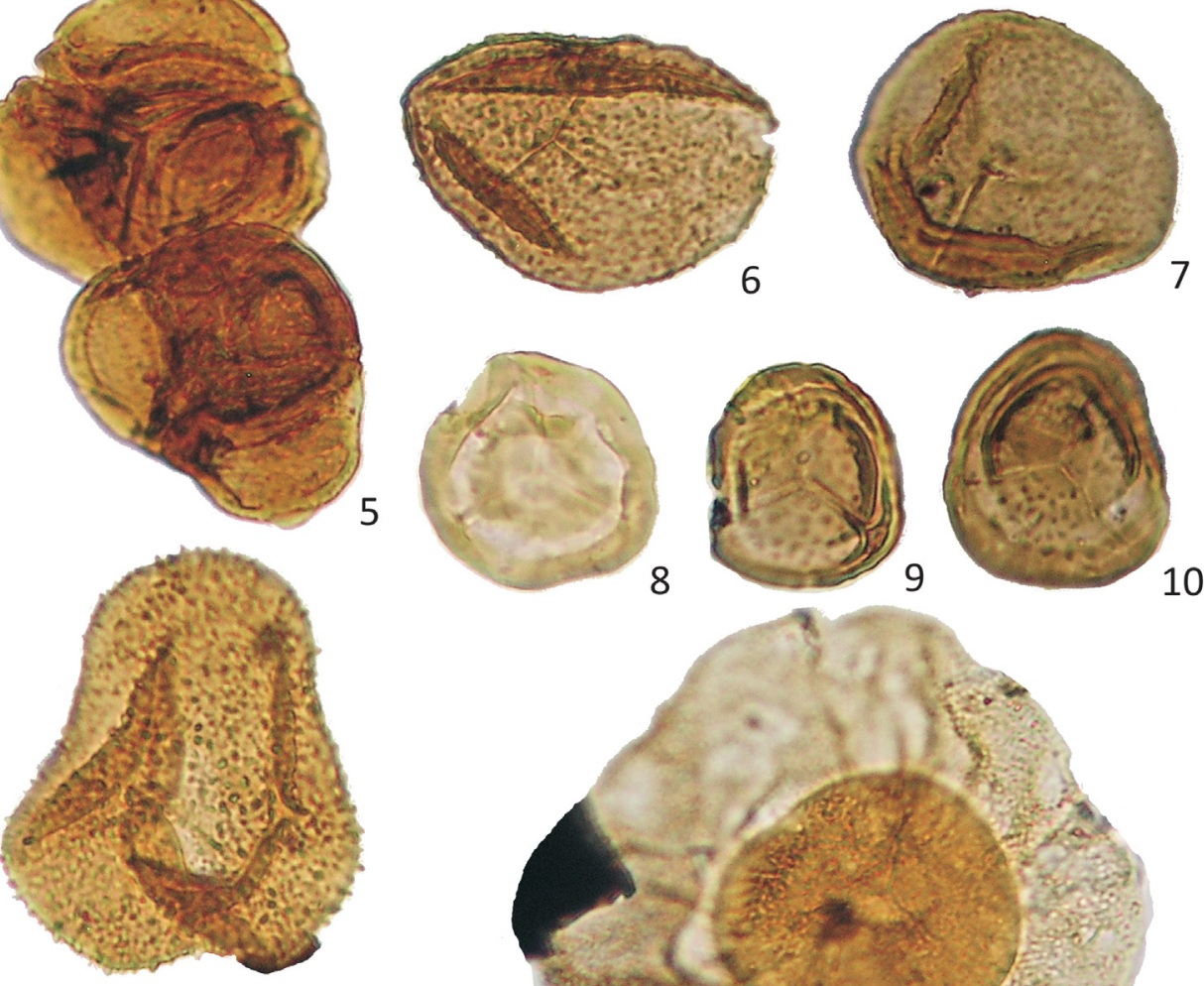

11
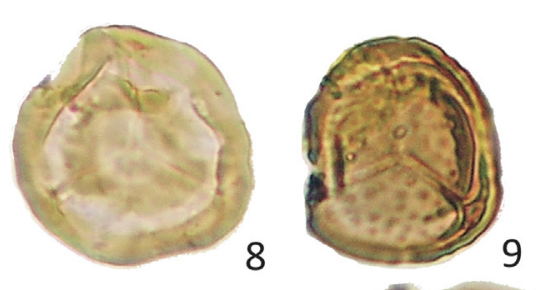

9
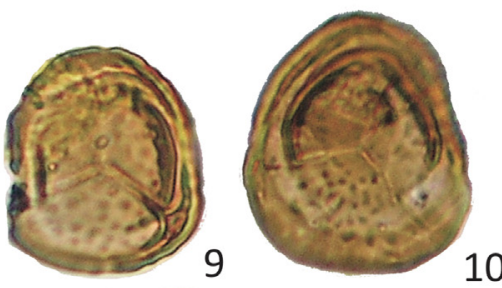

10

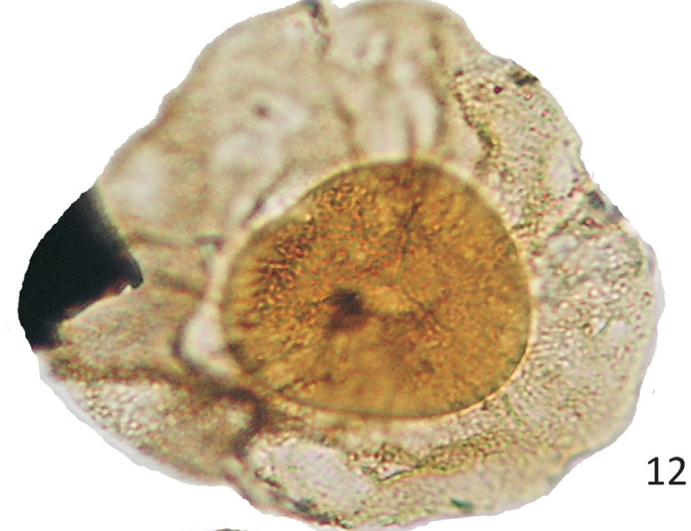

13

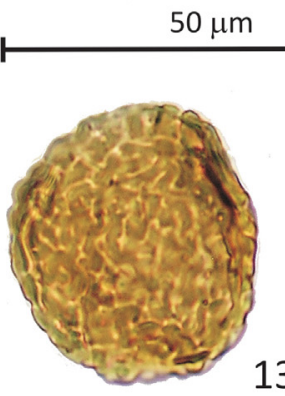

12 

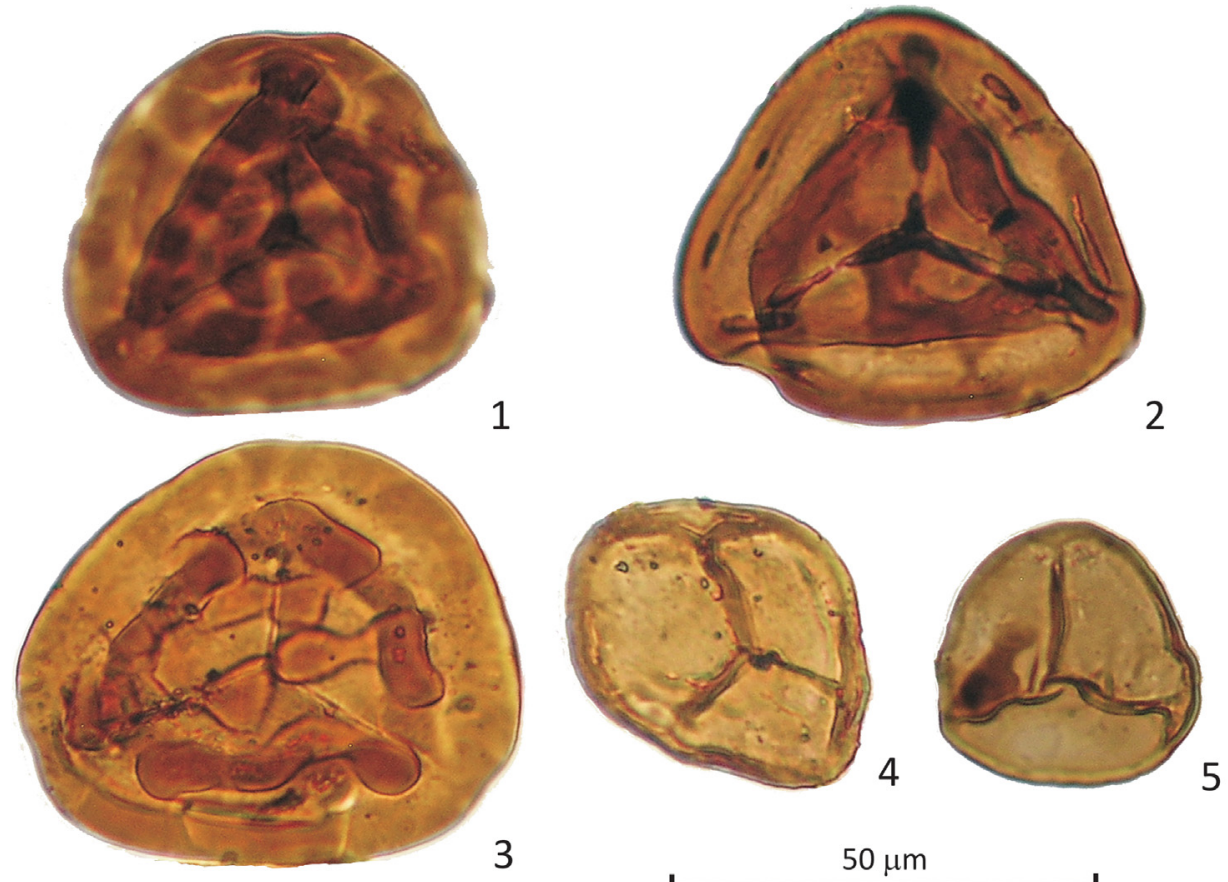

3

7
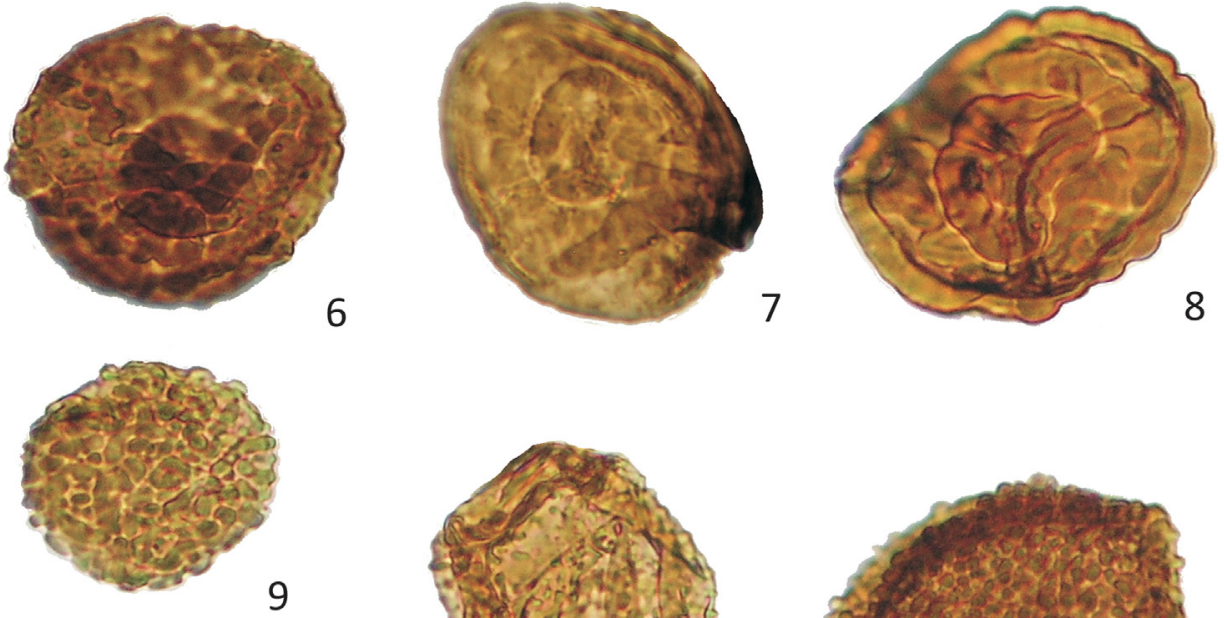

6

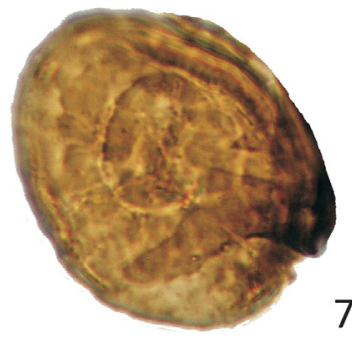

$50 \mu \mathrm{m}$
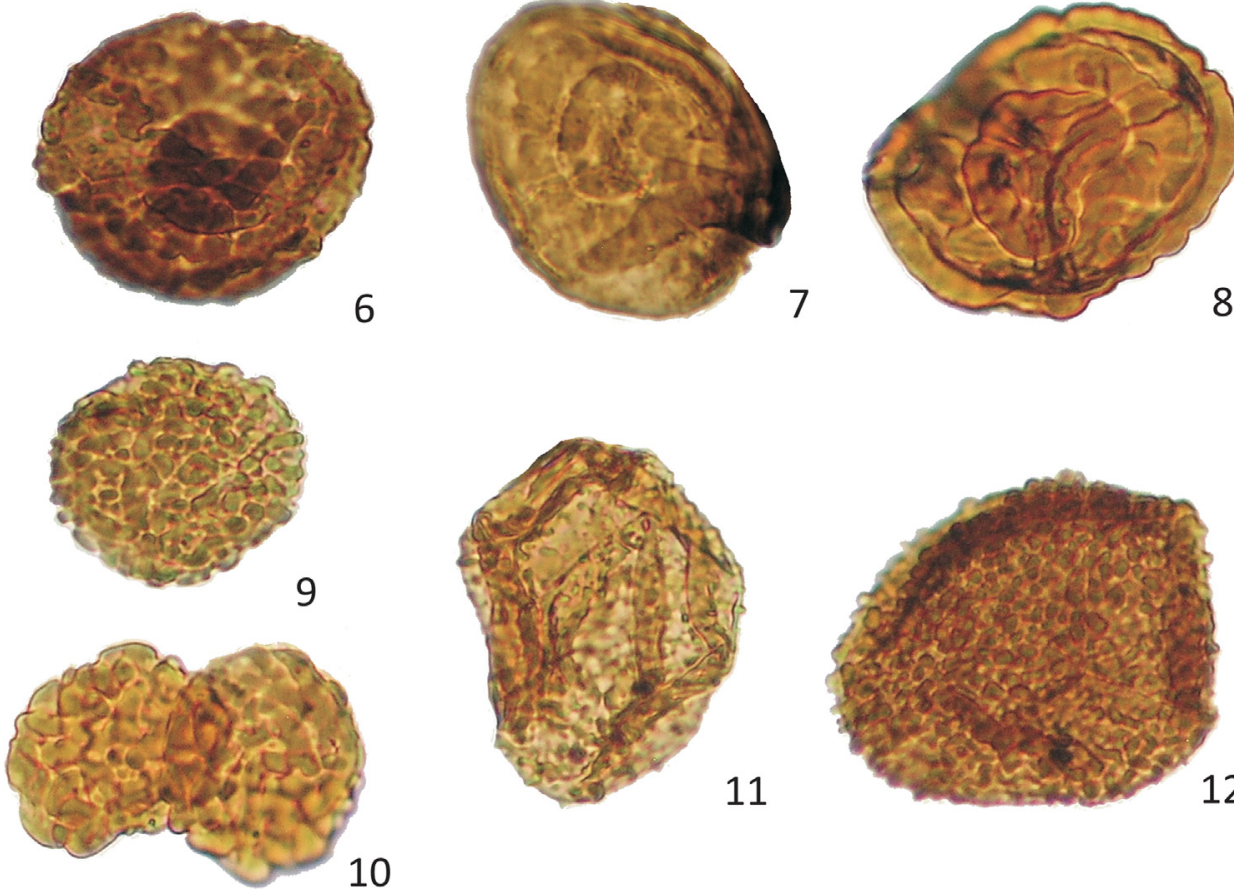

11

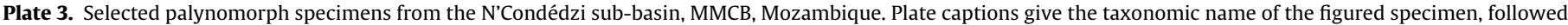

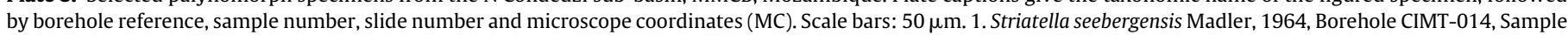

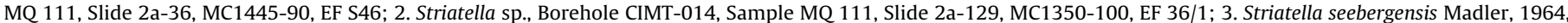

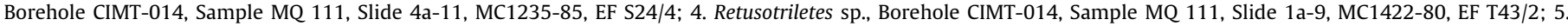

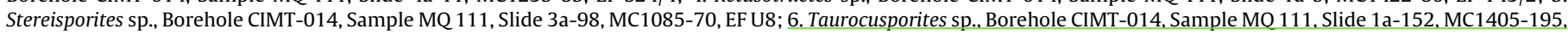

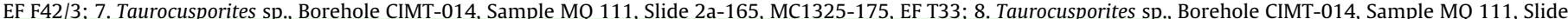

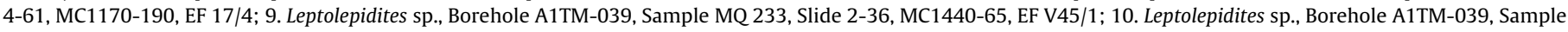

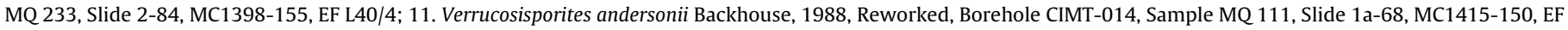
L42/4; 12. Verrucosisporites narmianus Balme, 1970, Borehole CIMT-014, Sample MQ 111, Slide 2a-172, MC1305-75, EF T31.

\subsection{Assemblage L2}

The assemblage contains abundant Alisporites spp. (including A. plicatus, A. potoniei and A. ovatus), Protohaploxypinus spp. (e.g., Protohaploxypinus amplus, P. goraiensis and P. limpidus) and Striatopodocarpites spp., together with rare to common Vittatina sp. and
Weylandites lucifer. Other rare to common pollen taxa occurring in this assemblage are Cycadopites sp., Lueckisporites virkkiae and Gnetaceaepollenites sinuosus, in addition to common Guttulapollenites hannonicus and Platysaccus sp.

The spores increase in abundance: taxa such as Brevitriletes sp. Baculatisporites bharadwaji, Baculatisporites sp., Calamospora 

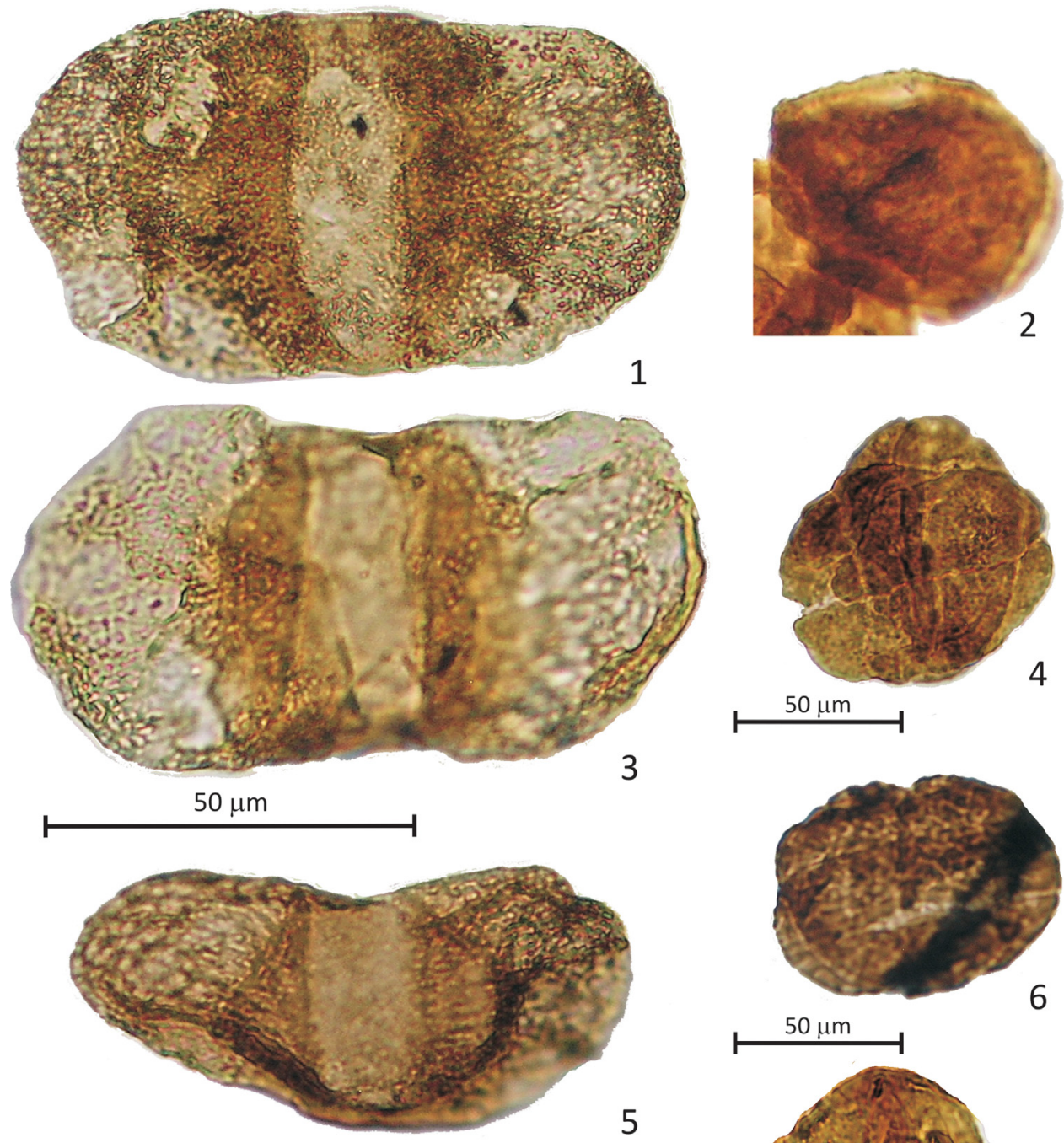

5
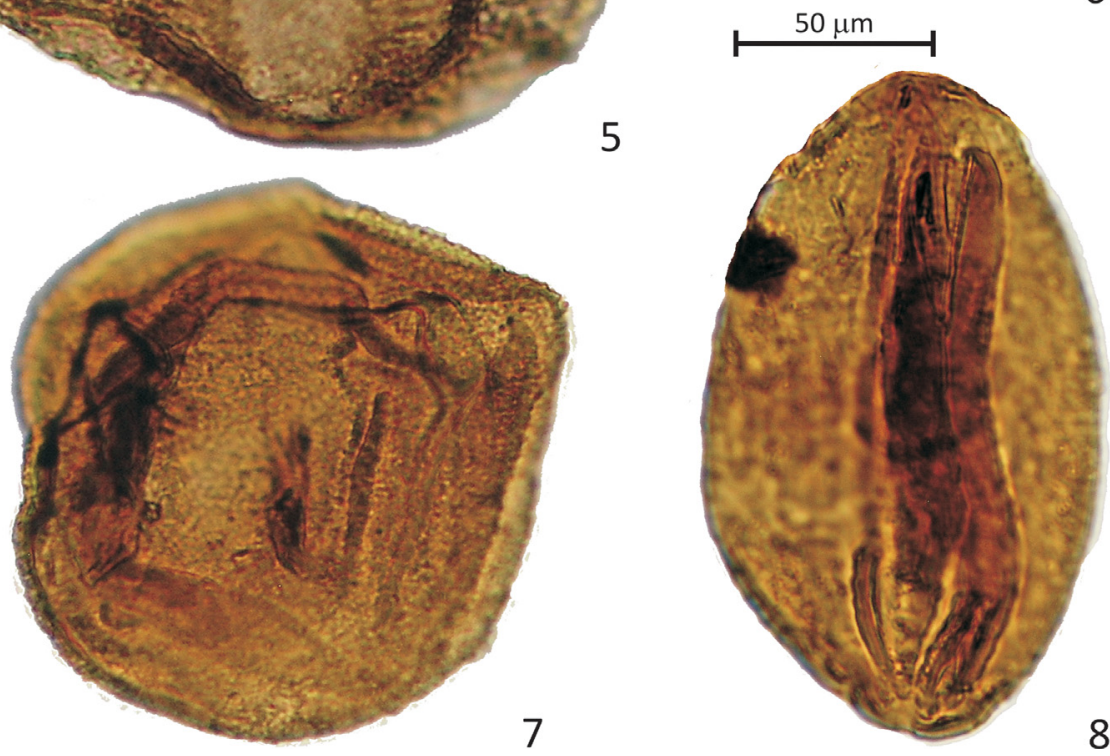

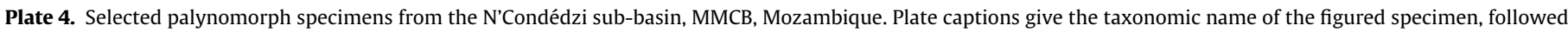
by borehole reference, sample number, slide number and microscope coordinates (MC). Scale bars: $50 \mu \mathrm{m}$. 1. Alisporites parvus de Jersey, 1962, Borehole CIMT-014, Sample MQ 111, Slide 1a-30, MC1415-55, EF 2V4; 2. Enzonalasporites vigens Leschik, 1955, Borehole A1TM-039, Sample MQ 232, Slide 1-1, MC1225-55, EF V26; 3. Alisporites parvus de Jersey 1962, Borehole A1TM-039, Sample MQ 232, Slide 2b-23, MC1225-42, EF X23; 4. Guttulapollenites hannonicus Goubin, 1965, Borehole CIMT-014, Sample MQ 156, Slide 1b-34, MC 1320-245, EF A33/3; 5. Platysaccus queenslandi de Jersey, 1962, Borehole CIMT-014, Sample MQ 111, Slide 2b-58, MC1295-185, EF H30/2; 6. Guttulapollenites hannonicus Goubin, 1965, Sondagem Borehole A1TM-039, Sample MQ 232, Slide 2b-4, MC1315-125, EF 032; 7. Densipollenites? sp., Borehole CIMT-014, Sample MQ 111, Slide 3a-31, MC1425-55, EF V43/4; 8. Gnetaceaepollenites sinuosus (Balme and Hennelly) Bharadwaj and Srivastava, 1969, Borehole CIMT-014, Sample MQ 147, Slide 1a-140, MC1373-41, EF W38/3. 

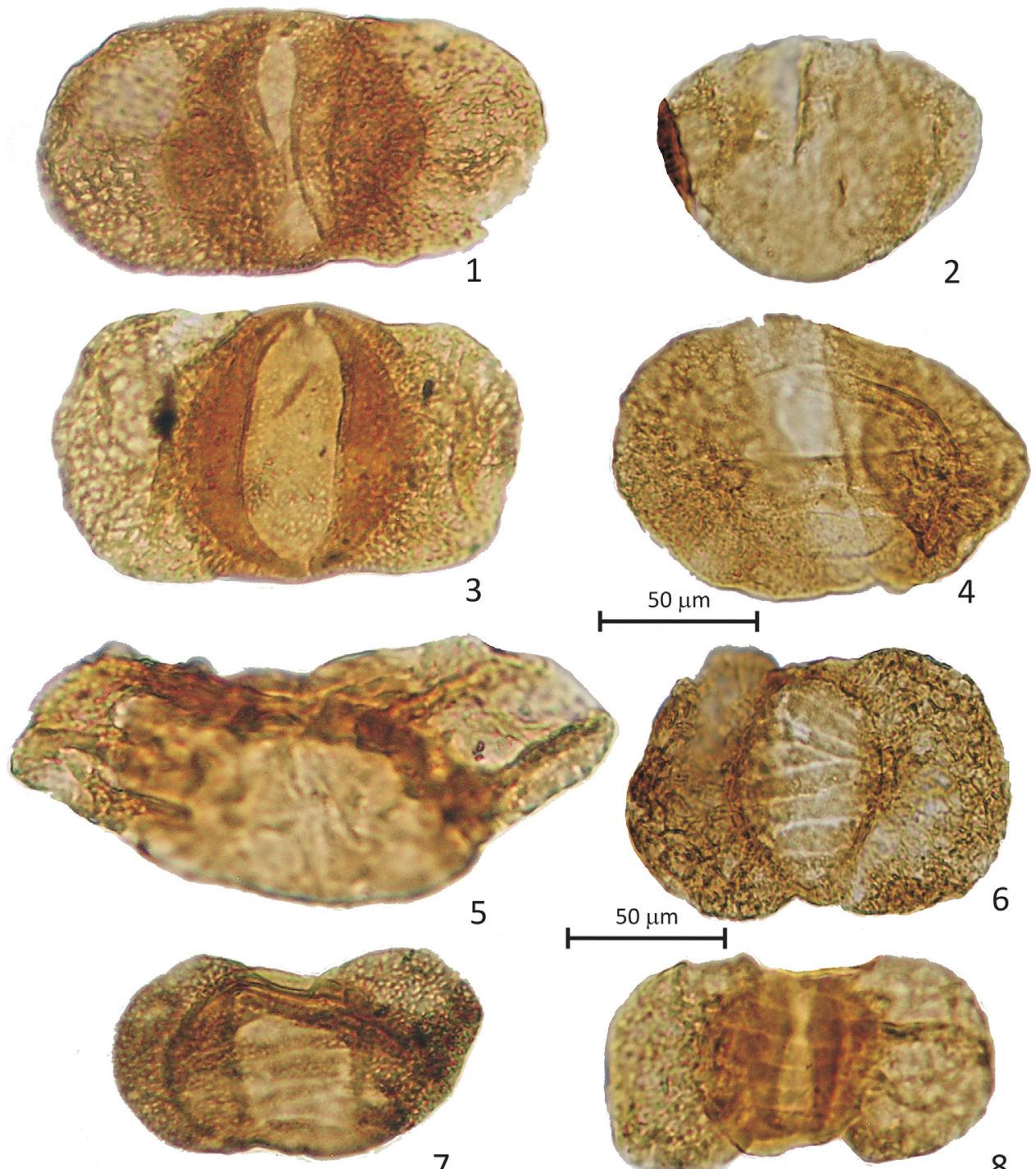

7
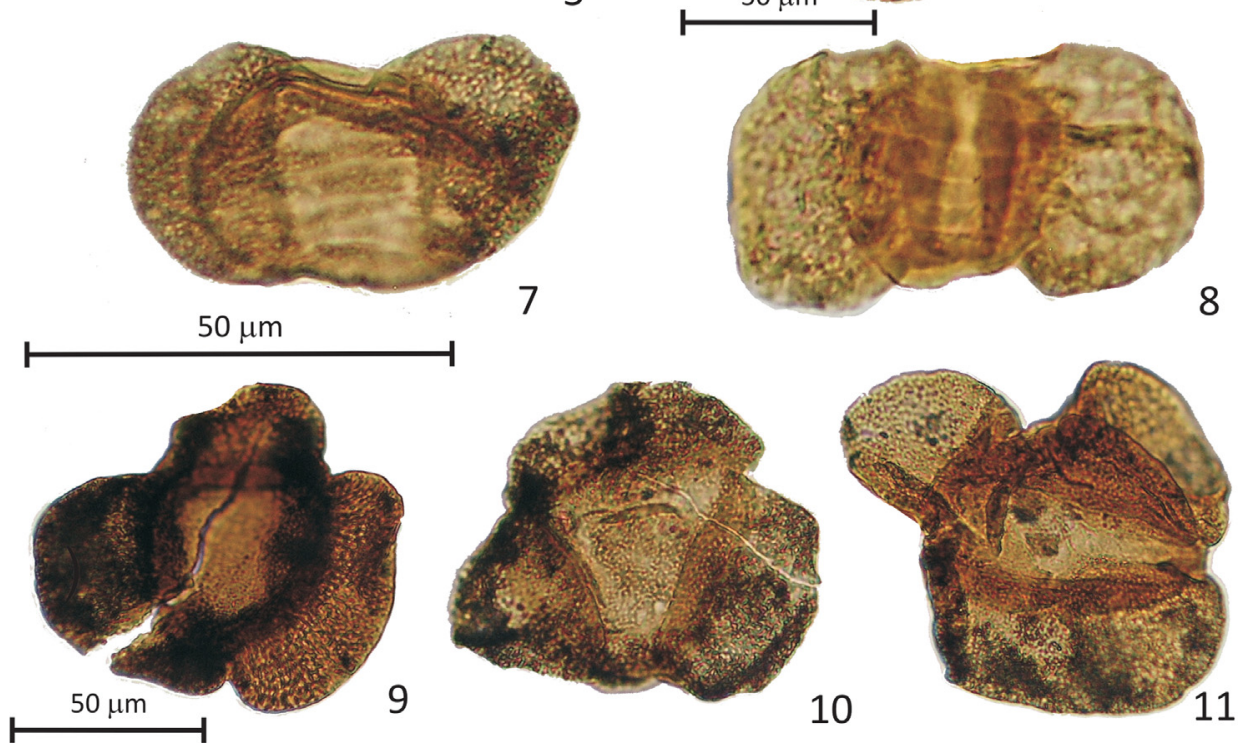

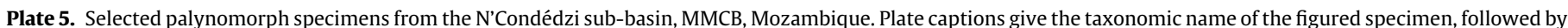

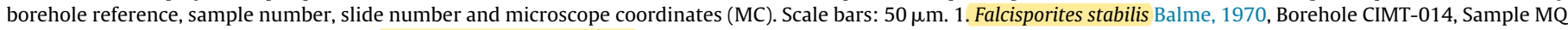

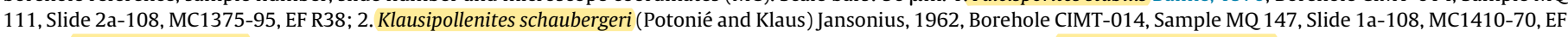

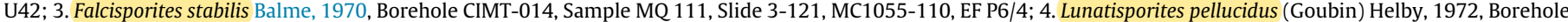

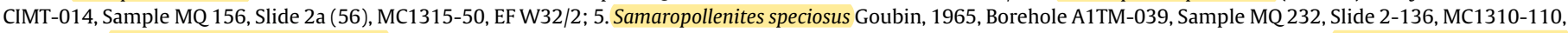

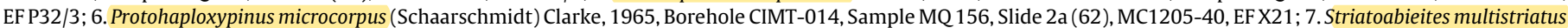

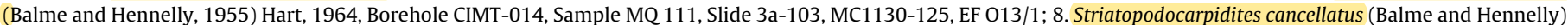

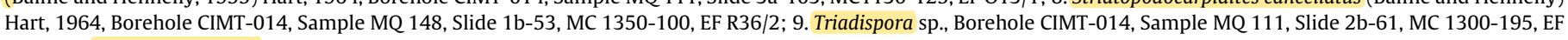

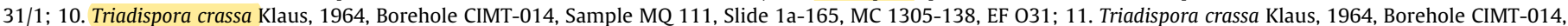
Sample MQ 111, Slide 4-93, MC 1170-200, EF F17/3. 
spp., Cyclogranisporites sp., Horriditriletes spp., Laevigatosporites spp., Leiotriletes sp., Microbaculispora trisina, Microbaculispora sp., Microgranulatisporites sp., Punctatisporites sp., Retusotriletes sp. and Verrucosisporites andersonii become more frequent within this interval. Common to abundant monolete spores include Polypodiisporites sp. and Thymospora pseudothiessenii, the latter occurring for the first time in this assemblage (Tables 2 and 3).

Occurrence: Borehole A1TM-058, sample interval MQ85 to MQ69 (barren sample below MQ68).

\subsection{Assemblage $L 3$}

This assemblage is characterised by a dominance of spores, in general presenting a better preservation than the pollen grains. The most common taxa include Apiculatisporis sp., Baculatisporites bharadwaji, Baculatisporites sp, Calamospora sp., Cyclogranisporites sp., Horriditriletes spp. (common $H$. tereteangulatus and rare H. ramosus), Leiotriletes sp., Microbaculispora sp., Microgranulatisporites sp. and Verrucosisporites andersonii and the monolete taxa Laevigatosporites spp. (L. colliensis, and L. vulgaris), Thymospora pseudothiessenii and Polypodiisporites sp. Common Lophotriletes sp., Osmundacidites senectus, Osmundacidites sp. and Kraeuselisporites sp. occur here for the first time.

The assemblage is complemented with common to abundant non-taeniate and taeniate bisaccate pollen grains such as Protohaploxypinus spp., Striatopodocarpites spp. (starting to decline within this assemblage) and Alisporites spp., together with rare to common Guttulapollenites hannonicus, Corisaccites sp. and Lueckisporites virkkiae. More scarcely, Limitisporites sp. and Platysaccus sp. are also present in the assemblage. The more common colpate pollen taxa are Gnetaceaepollenites sinuosus, Tiwarisporites sp., Vittatina spp., Weylandites lucifer and Weylandites magmus. Rare monosaccate pollen grains are also present (e.g., Cannanoropollis sp.).

Osmundacidites senectus and rare Protohaploxypinus microcorpus commonly occur together throughout assemblage L3 for the first time (Table 1). The upper part of assemblage L3 is marked by the first appearance of Klausipollenites schaubergeri.

Occurrence: Borehole A1TM-058, sample interval MQ68 to MQ45; Borehole CIMT-014, sample interval MQ 156 to MQ 148.

\subsection{Assemblage T1}

This assemblage is characterised by an increased abundance of the following spore taxa: Cyclogranisporites areosus, Granulatisporites sp., Horriditriletes tereteangulatus, Leiotriletes sp., Lophotriletes novicus, Osmundacidites senectus, Thymospora pseudothiesseni and Verrucatisporites sp. For the first time, the occurrence of rare to common Aratrisporites sp., Densoisporites nejburgii, D. playfordii, Densoisporites sp., Lundbladispora sp., Playfordiaspora cancellosa and Verrucosisporites narmianus is also a characteristic feature in this assemblage. The assemblage is complemented with common non-taeniate and taeniate bisaccate pollen grains such as Alisporites spp. and very rare Protohaploxypinus spp. (including rare Protohaploxypinus microcorpus). Cycadopytes sp., Corisaccites sp., Gnetaceaepollenites sinuosus, Guttullapollenites hannonicus, Hamiapollenites sp., Lueckisporites virkkiae, Lunatisporites pellucidus, L. noviaulensis, Lunatisporites sp., Klausipollenites schaubergeri and Weylandites lucifer also occur in the assemblage. Specimens of the genera Striatopodocarpites spp. and Protohaploxypinus spp. disappear within this assemblage and is associated to the last occurrence of the coal beds just below assemblage T1.

Occurrence: Borehole CIMT-014, sample MQ147 to MQ141.

\subsection{Assemblage $T 2$}

The assemblage is characterised by the increase in abundance of the following pollen taxa Alisporites spp. (A. landianus, A. parvus and A. tenuicorpus) and Falcisporites spp. (F. stabilis and Falcisporites sp.), complemented by the occurrence of Cycadopites sp., Densipollenites sp., Hamiapollenites sp. and Platysaccus queenslandi. Rare Gnetaceaepollenites sinuosus, Protohaploxypinus microcorpus, Lueckisporites virkkiae and Corisaccites sp. also extend their range into this assemblage. Rare to common Lunatisporites pellucidus, L. noviaulensis, Klausipollenites schaubergeri and Hamiapollenites spp. are also present in the assemblage (Table 3 ).

Common species from the preceding assemblages, as for instance, Protohaploxypinus limpidus, Striatopodocarpites cancellatus, Guttullapollenites hannonicus and Weylandites lucifer, have their last occurrence in this assemblage.

The spores are common to abundant, particularly Aratrisporites sp., Calamospora landiana, Cyclogranisporites sp., Densoisporites complicatus, D. nejburgii, D. playfordii, Densoisporites sp., Leiotriletes adnatus, Lophotriletes novicus, Lundbladispora spp., Osmundacidites senectus, Playfordiaspora cancellosa, Punctatisporites spp. and Verrucosisporites narmianus.

The presence of common to rare Convolutispora sp., Leiotriletes directus and Microbaculatisporites sp., as well as common to abundant Polypodiisporites sp. and Thymospora sp. are interpreted as reworked. Spore UV fluorescence analysis on non-oxidized palynological residues confirms this feature. The reworked spores show dark orange fluorescence colours or have no fluorescence, whereas the indigenous palynomorph population shows intense yellow fluorescence colour, indicating lower organic maturation levels than the reworked population (Galasso et al., 2019).

Occurrence: Borehole CIMT-014, sample MQ 127 to MQ 115.

\subsection{Assemblage $T 3$}

This assemblage is characterised by the common presence of pollen grains such as Alisporites spp. (A. landianus, A. parvus and A. tenuicorpus), Falcisporites spp. (F. stabilis and Falcisporites sp.) and very rare Protohaploxypinus microcorpus. Rare Densipollenites spp., Hamiapollenites insolitus and Samaropollenites speciosus, as well as common Hamiapollenites sp., Platysaccus queenslandi, Vittatina spp. and Weylandites magnus are also present in this assemblage.

Rare monosacate pollen grains were also observed (Striatomonosaccites ovatus Cannanoropolis sp., Triadispora crassa and Triadispora sp.). The samples of borehole A1TM-039 also contain rare Enzonalasporites vigens (Table 3).

The spores assemblage is marked by the income of new species such as Anapiculatisporites spiniger (=Carnisporites anteriscus), Anapiculatisporites sp., Cingutriletes sp., cf. Dictyophyllidites sp., Leiotriletes adnatus, Leptolepidites sp., Limatulasporites limatulus, Lundbladispora obsoleta, Nevesisporites fossulatus, Stereisporites sp., Striatella seebergensis, Striatella sp. and Taurocusporites sp. Rare Aratrisporites sp., Calamospora landiana, Cyclogranisporites sp., Lophotriletes novicus, Densoisporites spp., Lundbladispora brevicula, Playfordiaspora cancellosa, Verrucosisporites narmianus and Verrucatisporites sp. are observed in the assemblage.

Cyclogranisporites sp., Leiotriletes sp., Pyramidosporites sp., Microbaculispora sp. and Verrucosisporites sp., Verrucosisporites andersonii are rare, and Osmundacidites senectus, Polypodiisporites sp. and Thymospora spp., commonly present, are all interpreted as reworked. Similar to what was observed in the previous assemblage (T2), in non-oxidized palynological residues, the reworked palynomorph population shows dark orange fluorescence colours or no fluorescence. Again, this feature is in clear contrast with the bright yellow fluorescence colours of the indigenous palynomorph population (Galasso et al., 2019). 
Occurrence: Borehole CIMT-014, sample MQ 111; Borehole A1TM-039, sample interval MQ233 to MQ 231.

All assemblages present rare specimens of algae and incertae sedis, including Peltacystia venosa and Peltacystia sp. (Zygnemataceae algae), as well as Cymatiosphaera gondwanensis, Mehlisphaeridium sp. and Leiosphaeridia sp. (Prasinophyceae algae; Riboulleau et al., 2018; Spina et al., 2018a), and rare Reduviasporonites chalastus (incertae sedis organic microfossil, Spina et al., $2015,2018 b$ ). Several fungal remains (hyphae) and root hairs are also observed.

\section{Palynostratigraphic age interpretations}

The N'Condedzi sub-basin palynomorph assemblages identified in the present research are assigned to the Lopingian (late Permian), Lower Triassic, and reach the basal Upper Triassic (Carnian). The present study not only confirms the three assemblages proposed by Pereira et al. (2019) for the Lopingian sediments of the Muarádzi sub-basin but also allowed the characterization of three new assemblages of Triassic age. Assemblage L1 is characterised by the prominence of taeniate bisaccate Protohaploxypinus spp. and Striatopodocarpites spp., as well as the non-taeniate Alisporites spp., which are long ranging taxa. The abundant occurrence of Guttulapollenites and Weylandites is a defining feature in this assemblage. To this assemblage, a possible early Lopingian age is assigned (Fig. 4).

Assemblage L2 is marked by the FO of Thymospora pseudothiessenii and includes as other characteristic taxa Indotriradites sp., Kraeuselisporites spp. and Polypodiisporites spp. (Fig. 4). These taxa occur for the first time in this assemblage. A mid Lopingian age could be assigned to this assemblage.

Assemblage L3 is defined by the FO of Osmundacidites senectus, Klausipollenites schaubergeri and rare Protohaploxypinus microcorpus (Fig. 4), completes the assemblage the taxa described for the two preceding assemblages. This assemblage could be assigned to late Lopingian.

Assemblage T1 is defined by the FO of Densoisporites nejburgii (Fig. 4). The assemblage includes Aratrisporites sp., D. playfordii, Densoisporites sp., Lundbladispora spp., Playfordiaspora cancellosa and Verrucosisporites narmianus, the latter has its FO in the assemblage. To this assemblage is assigned an Induan age (early Triassic).

Assemblage T2 presents a change in the palynomorph group abundances. The non-taeniate bisaccate gymnosperm pollens such as Alisporites parvus, Falcisporites stabilis and Falcisporites sp. are abundant and occur for the first time in the present assemblage (Fig. 4). The FO of Platysaccus queenslandi and Densipollenites sp. is also observed (Fig. 4). This assemblage could be assigned to Olenekian (Lower Triassic). The assemblage is also characterised by the disappearance of important species such as Alisporites plicatus, Cannanoropollis sp., Guttullapollenites hannonicus, Protohaploxypinus limpidus, Striatopodocarpites cancellatus, Vittatina sp. and Weylandites lucifer.

In assemblage T3, Anapiculatisporites spiniger (=Carnisporites anteriscus), cf. Dictyophyllidites sp., Leiotriletes adnatus, Leptolepidites sp., Limatulasporites limatulus, Lundbladispora obsoleta, Nevesisporites fossulatus, Stereisporites sp., Striatella seebergensis, Striatella sp. and Taurocusporites sp., as well as rare Samaropollenites speciosus and Enzonalasporites vigens occur for the first time (Fig. 4). This assemblage is assigned to Carnian.

Assemblages T2 and T3 present common reworked spores of Lopingian age or older (Cyclogranisporites sp., Osmundacidites senectus, Polypodiisporites sp. and Thymospora sp.). This feature was confirmed by the UV fluorescence colour of the non-oxidized spores, and permitted to identify and confirm an erosive episode that occurred in the MMCB during the Middle Triassic (Fernandes et al., 2015; Galasso et al., 2019). The identification of palynomorphs reworking is critical (Lindström and McLoughlin, 2007; di Pasquo et al., 2017) in particular in the stratigraphic sequences related to mass-extinctions events, as for instance the Permian-Triassic Boundary (PTB). Osmundacidites senectus appears not to have been greatly affected by the PTB extinction-event as it is corroborated by different studies in other localities, e.g., Antarctica (Lindström and McLoughlin, 2007) and Madagascar (Msaky and Srivastava, 1997), it is common in the late Permian of Gondwana, presenting a great decline in the early Triassic. Other species such as Lophotriletes sp. and Leiotriletes directus are also present throughout PTB time interval (Lindström and McLoughlin, 2007) but not present in Upper Triassic. In the MMCB, the common presence of these taxa in the Upper Triassic sedimentary rocks is interpreted as reworked inferred from UV spore fluorescence colours (Galasso et al., 2019), being an independent tool to estimate the degree of reworking at these ages.

\section{Sratigraphical significance of the palynoflora and correlations across Gondwana}

The palynostratigraphic characterisation of the PTB across the Gondwana Supercontinent has been a matter of debate for a long time. The typical microflora of dominant gymnosperms pollen vegetation, at the end of the Permian period, change to the abundant lycophyte spore producing vegetation, in the early Triassic, has been discussed by several authors (Steiner et al., 2003; Lindström and McLoughlin, 2007; Pereira et al., 2016). The latest Permian palynostratigraphic correlation synthesis across Gondwana is presented in Pereira et al. (2019). Thus, the present paper will discuss the correlations of the PT boundary (also described in Pereira et al., 2016), as well as of the Lower and Upper Triassic. The palynofloral record from MMCB shows a discrete floral change at the PT boundary. The spore and pollen diversity presents some decrease during the lowermost Triassic and the assemblages show a mixed Permian-Triassic feature, composed of common gymnosperms pollen and lycophyte spore with the income of new spore taxa. This fact is observed in other central Gondwana PT boundary sections as for instance Kenya, Tanzania, Zambia, South Africa, Madagascar, Pakistan, and Antarctica (Lindström and McLoughlin, 2007; Hochuli et al., 2010; Hermann et al., 2012; Hermann and Bucher, 2015) and also in other palaeogeographic areas (e.g., Italy, Southern Alps, Cirilli et al., 1998; Spina et al., 2015).

Although independent age constrains are missing in this study, the assemblages described are tentatively correlated with the stratigraphic records of different Karoo basins already studied in Mozambique (Pereira et al., 2016, 2019). The Lopingian main assemblages (L1, L2 and L3) recognized in the N'Condédzi subbasin perfectly correlate with the assemblages established for the Muarádzi sub-basin (Pereira et al., 2019). This characteristic indicates that the palynostratigraphy of the sub-basins can be easily correlated across the MMCB.

According to Foster et al. (1998) and Lindström and McLoughlin (2007), the late Lopingian key-taxa of the PT boundary in Gondwana are Lunatisporites pellucidus and Aratrisporites spp. However, Aratrisporites spp. can be considered facies dependent (Retallack, 1977).

In Mozambique, L. pellucidus occurs infrequently in the latest Permian, becoming more abundant in the early Triassic assemblages. The early Induan is marked by the FO of Densoisporites nejburgii and Aratrisporites sp. Neither of these key-taxa is very abundant in the studied sections, but both occur for the first time in the lowermost Triassic successions (Borehole CIMT-014 and Fig. 4). The following Olenekian interpreted age assemblage (Assemblage T2) is marked by the income of new pollen 
species (Alisporites parvus, Falcisporites stabilis, Falcisporites spp. and Platysaccus queenslandi) (Fig. 4), as well as common spores such as Densoisporites complicatus, Leiotriletes adnatus and Lundbladispora obsoleta.

In the Lower Triassic of central Gondwana, other significant species defining the lowermost boundary are Playfordiaspora cancellosa and Triplexisporites playfordi (Wright and Askin, 1987; Hankel, 1993; Foster et al., 1994; Lindström and McLoughlin, 2007). Playfordiaspora cancellosa is rare to common in the early Triassic in Mozambique, and Triplexisporites playfordii was never recovered in this study, as well as in other MMCB palynological studies (Pereira et al., 2016).

\subsection{The late Permian and the early Triassic}

The latest Permian-Triassic palynomorph assemblages in Central Gondwana, studied in Kenya (Hankel, 1992), presents an assemblages dominated by taeniate bisaccate pollen. The lowermost Triassic succession is missing, but the early Triassic characteristic taxa present are Densoisporites sp., Lunatisporites pellucidus, Lundbladispora willmottii, Playfordiaspora cancellosa, Protohaploxypinus microcorpus and Triplexisporites playfordii. In Kenya, T. playfordii and $P$. cancellosa are not recorded in the early Triassic assemblages, but they occur in a younger assemblage (Hankel, 1991, 1992). The Induan assemblage in Kenya is very similar to the Assemblage T1 described in this study for the N'Condedzi sub-basin succession.

In Tanzania (Hankel, 1987; Msaky and Srivastava, 1997), the PT boundary is present in the Hatambulo Formation and is marked by the occurrences of common Lueckisporites sp., Guttulapollenites hannonicus, Striatopodocarpites spp. and Protohaploxypinus spp. (late Permian), as well as Alisporites sp., Apiculatisporites sp., Densipollenites sp., Playfordiaspora cancellosa and Platysaccus sp. This association is also very similar to the Assemblage T1 described for the N'Condédzi sub-basin succession, whereas Playfordiaspora cancellosa is recorded in the late Middle Triassic of Tanzania.

In southern Zambia (Mid-Zambezi Valley section), the late Permian assemblages include Guttulapollenites hannonicus, Thymospora pseudothiessenii and Weylandites lucifer, that can be correlated with Assemblage L2 of late Wuchiapingian age, in the Muarádzi and the N'Condédzi sub-basins (Pereira et al., submt; and in this study). The early Triassic is missing in this region, but then the late Lower Triassic (Olenekian) is marked by the presence of Alisporites spp., Aratrisporites ficheri, Falcisporites stabilis, Lunatisporites pellucidus, Platysaccus queenslandii, Playfordiaspora cancellosa, Sulcatisporites sp., Uvaesporites sp. and Verrucosisporites sp. (Nyambe and Utting, 1997). The assemblage closely resembles the Assemblage T2 described in this study for the N'Condédzi subbasin.

To the latest Permian sequence in Zimbabwe (Mid-Zambezi Basin) Zone IV, Subzones $\mathrm{H}$ and $\mathrm{H} 1$ (Protohaploxypinus subassemblage) are assigned. The early Triassic succession is characterised by the transitional Protohaploxypinus-Alisporites spp. assemblage (Falcon, 1975, Falcon et al., 1984). The correlation with the Muarádzi and the N'Condédzi sub-basins remains difficult.

In South Africa, according to Steiner et al. (2003), the late Permian-early Triassic zonation includes two biozones: the Klausipollenites schaubergeri Zone, which is characterised by Falcisporites spp., Playfordiaspora cancellosa, Protohaploxypinus sp. and Triplexisporites playfordii (these two last species are common in the late Permian, but are not recorded in the early Triassic in this region), and the Kraeuselisporites-Lunatisporites Zone, dominated by lycopsid species such as Kraeuselisporites spp., Lundbladispora spp. and Lunatisporites spp. (including L. pellucidus and L. noviaulensis). The Klausipollenites schaubergeri zone is clearly different from the assemblages described from Mozambique (suggested in this study and in Pereira et al., 2019). Even so, the KraeuselisporitesLunatisporites zone enables a comprehensive correlation with the early Triassic Assemblage T1, based on the presence of Lundbladispora spp., and Lunatisporites spp.; however, key species recorded in the N'Condédzi sub-basin are missing in South Africa, such as Densoisporites nejburgii and Aratrisporites spp.

The upper Triassic successions of Madagascar (Gobin, 1965; Wright and Askin, 1987; Hankel, 1993) comprise common to abundant Lunatisporites pellucidus (occurring for the first time in latest Permian) and an increase in the abundance of Striatopodocarpites pantii. Common Protohaploxypinus spp. and lycopsids spores such as Densoisporites spp., Lundbladispora sp., Kraeuselisporites spp. (mostly in the lower part), as well as Ephedripites sp, Limatulasporites fossulatus, Playfordiaspora cancellosa, Striomonosaccites morondavensis, and Triplexisporites playfordii and rare Guttulapollenites hannonicus and Weylandites spp. are also part of the assemblage. This assemblage can be correlated with the Assemblage T1 described in the N'Condédzi sub-basin, except for the presence of Triplexisporites playfordii, which was never recorded in the MMCB successions.

In Pakistan (Balme, 1970; Hermann et al., 2012; Hermann and Bucher, 2015), the Permian-Triassic succession at Amb, Salt Range, is characterised by the occurrence of Acanthotriletes tereteangulatus, Dictyophyllidites harrisii, Falcisporites australis, Kraeuselisporites spp., Guttulapollenites hannonicus, Protohaploxypinus spp. (including P. microcorpus), Triquitrites proratus and Sulcatisporites ovatus. The early Triassic assemblage contains several typical Permian taxa, as well as new Triassic taxa such as Protohaploxypinus varius, Cycadopites spp., Densoisporites spp. and Lunatisporites spp., Lundbladispora spp., that could be direct correlated with the Assemblage T1 described in the N'Condédzi sub-basin. Triplexisporites playfordii was not recorded in the early Triassic assemblages of Pakistan but occurs higher in the stratigraphic section (Balme, 1970; Hermann et al., 2012; Hermann and Bucher, 2015). Playfordiaspora cancellosa is observed also in the early Triassic (Balme, 1970) and is comparable to the N'Condédzi sub-basins record.

In India, several studies (e.g., Srivastava and Jha, 1990; Jha and Srivastava, 1996; Jha, 2006; Jha et al., 2018) describe in the early Triassic the palynoassemblage $\mathrm{X}$, which is characterised by the increase in the Lunatisporites species, and the decline in the percentage of striate bisaccate pollen grains (such as Striatopodocarpites spp. and Faunipollenites spp.). The assemblage also contains Crescentipollenites, Densipollenites, Klausipollenites, Alisporites and Lundbladispora. Palynoassemblage XI (Olenekian age) is characterised by the dominance of Lundbladispora spp. and Densoisporites spp., along with the occurrence of Striatopodocarpites spp., Faunipollenites spp. and Crescentipollenites spp. The stratigraphically significant taxa of this palynoassemblage are Araucariacites sp., Brachysaccus ovalis, Chordasporites sp., Falcisporites nuthallensis, Klausipollenites schaubergeri, Playfordiaspora cancellosa, Ringosporites fossulatus and Staurosaccites marginalis. Tentatively, the assemblage correlation with Assemblage T1 is based on common presence of Lundbladispora spp. and Densoisporites spp.

In the Prince Charles Mountain succession, in Antarctica (Foster et al., 1994; Lindström and McLoughlin, 2007), the early Triassic succession is marked by the occurrence of Lunatisporites spp., Protohaploxypinus microcorpus, P. samoilovichii, Falcisporites spp. and Alisporites spp., with common Brevitriletes spp., Leiotriletes directus, Osmundacidites spp. and Dictyophyllidites spp. A high diversity and abundance of lycopsid spores, mainly Densoisporites spp. (Densoisporites nejburgii), Lundbladispora spp., Kraeuselisporites ssp. and Uvaesporites spp. was also registered. This latter assemblage can be correlated with Assemblage T1 described for the N'Condédzi subbasin. T. playfordii and $P$. cancellosa are not observed in these late 
Permian successions; however, their first appearance occur in early Triassic rocks.

\subsection{The Upper Triassic}

The Carnian palynoflora of Gondwana is constrained by latitudinal and climatic factors, showing a distinct provincialism (Artabe et al., 2003; Dolby and Balme, 1976; Foster et al., 1994; Buratti and Cirilli, 2007; Cirilli, 2010), with two major palynofloral provinces recognized in the southern hemisphere: the Onslow and the Ipswich microflora.

The Onslow microflora is recognized in Northwestern Australia, Timor, extending through the western Tethys coasts (e.g., present coordinates north and eastern Africa, Sicily, Tunisia, Libya, Israel, India and Madagascar) and Western Europe, representing a warm temperate climate that established along these continental margins (Foster et al., 1994; Dolby and Balme, 1976; Buratti and Cirilli, 2007; Cirilli, 2010; Césari and Colombi, 2013, 2016; Cirilli et al., 2015, 2018). This microflora is characterised by the presence of mixed taxa typical of Northern Europe and South Gondwana, comprising the following taxa: Aulisporites, Camerosporites, Enzonalasporites, Duplexisporites, Infernopollenites, Minutosaccus, Ovalipollis, Samaropollenites and Weylandites, species typical of warm temperate climates. All of these species are absent in the Ipswich Microflora, which is characterised by the presence of taxa typical of cool temperate climate. Ipswich Microflora is depicted by the abundance of bisaccate pollen, monosulcate pollen and trilete spores. The Ipswich Microflora extends from southern and eastern Australia, Antarctica, South Africa and the Western margin of South America (Argentina and Chile).

The key species for the Carnian Onslow Microflora are Samarisporites speciosus and Enzonalasporites vigens (Dolby and Balme, 1976; Cirilli, 2010). In East India (Tripathi and Raychowdhuri, 2005), it has been correlated with the Rimaesporites potoniei/Samaropollenites speciosus Assemblage Zone of the Godavari Basin (Prasad, 1997). Hankel (1987) recognized the Staurosaccites quadrifidus Microflora, Samaropollenites speciosus and Minutosaccus crenulatus Microflora of Carnian-early Norian age in Tanzania (Luwegu Basin). These palynofloras could be correlated with Samaropollenites speciosus defined by Dolby and Balme (1976) in Western Australia.

In Mozambique, a Carnian assemblage was identified for the first time in two boreholes (boreholes CIMT-014 and A1TM-039) (Fig. 3) and presents several similarities with the Onslow Microflora. The significant species present are Samarisporites speciosus and Enzonalasporites vigens, assorted with distinctive cosmopolitan species (Anapiculatisporites spiniger/Carnisporites anteriscus, cf. Dictyophyllidites sp., Limatulasporites limatulus, Nevesisporites fossulatus, Stereisporites sp., Striatella seebergensis, Striatella sp. and Taurocusporites sp.). All these taxa are recorded for the first time in the upper Triassic successions in Mozambique, allowing the recognition of a mixed signature microflora. These results are preliminary, and ongoing studies have to confirm and better characterise this feature.

\section{Stratigraphic record and its implication to interbasinal correlation}

Conglomerates positioned immediately above the basement rocks in the Mozambican Karoo basins are frequently attributed to the Vúzi Formation (GTK Consortium, 2006) and are interpreted as tillites or fluvio-glacial deposits resulting from the end Carboniferous-early Permian Gondwana glaciation. The Vúzi Formation is correlated to the top of the Dwyka Group of the Main Karoo Basin, and therefore, a late Carboniferous to early Permian age is attributed to this formation based only on lateral lithological correlations (GTK Consortium, 2006; Paulino et al., 2010; Lakshminarayana, 2015). However, the presence of red clastic lithologies between the basement rocks and the conglomerates (A1TM-058), suggests deposition under more temperate climatic conditions in an oxidizing sub-aerial environment rather than glacial to periglacial environments. Moreover, the conglomerate beds identified in the Muarádzi sub-basin ranging in age from the Cisuralian-Guadalupian boundary (Lopes et al., 2014; Pereira et al., 2014) to Lopingian in borehole A1TM-058 and others boreholes (Pereira et al., 2019) indicate that there are several conglomerate beds of different ages intercalated in the stratigraphic successions of the Moatize and Matinde formations. Therefore, not all conglomerate beds positioned immediately above the basement are the product of glacial processes. If all conglomerate beds found in the last stratigraphic position are considered glacial deposits, glacial environments persisted in this region until the Lopingian, which is unlikely and not documented in any of the other Gondwana basins of Southeast Africa (Wopfner, 1999; Catuneanu et al., 2005). The palynological age of the conglomerate beds located immediately above crystalline basement rocks (Lopes et al., 2014; Pereira et al., 2014, 2016, 2019) indicates that not all of these sedimentary rocks should be considered as part of the Vúzi Formation. Therefore, we consider that the conglomerates at the base of borehole A1TM-058 could correspond to syntectonic sediments of Lopingian age, which probably marks the main phase of faulting within tectono-structural development of the basin. Accordingly, these conglomerates could represent coarse clastic sedimentary rocks deposited in alluvial fans that formed at the toe of the normal faults delimiting this Karoo Mozambique basin. This assumption also implies that conglomerate beds cannot be used as marker beds used for separating the different lithostratigraphic formations as they occurs interbedded both in the successions of the Moatize and Matinde formations. Thus, a better, clearer and formal definition for the stratigraphic boundary between these two units is needed. For example, if the conglomerate beds present at the base of borehole A1TM-058 (Fig. 3) were considered the base of the Matinde Formation, the minimum thickness for the latter formation is, therefore, $c a .1000 \mathrm{~m}$, which is the measured succession of the borehole and coal deposition persisted in this sub-basin until the end-Permian. However, if the conglomerate beds of the same borehole were considered the Vúzi Formation, the $c a .1000 \mathrm{~m}$ of coal-bearing sedimentary rocks above belong to the Moatize Formation. Because there are no major lithological changes in this $c a$. $1000 \mathrm{~m}$ thick succession, it is impossible to identify and place the boundary between the Moatize and Matinde formations within this succession.

The change from coal depositional environments to red beds successions, observed at the bottom of borehole CIMT-014 (Fig. 3), marks an important change in the depositional environments and palaeoclimatic conditions, which coincides approximately, with the Permo-Triassic boundary. According to the palynological studies done in the MMCB (Lopes et al., 2014; Pereira et al., 2014, 2016, 2019), this PT boundary also establishes the limit between the Matinde and the Cádzi formations. Therefore, most of the succession of borehole CIMT-014, as well as all the succession of borehole A1TM-039, belong to the Cádzi Formation. Within the Cádzi Formation, after the red bed deposition in the early Triassic, a phase of erosion occurred, marked by a Middle Triassic hiatus, followed by the deposition of upper Triassic red beds dated by palynomorphs, together with reworked Permian palynomorphs, probably sourced from the nearest Karroo basins (Galasso et al., 2019). The Cádzi Formation red beds succession of Triassic age yielded some rich spore levels, which could be associated to the increase of seasonal rainfall episodes or to possible changes in the river systems (from meandering to braided) (Ward et al., 2000). 
Tectonics and palaeoclimates were the main factors responsible for the different lithofacies recorded in the Permo-Triassic Karoo basins (Catuneanu et al., 2005). The high sedimentation rates observed in the Mozambique Karoo basins lead to the accumulation of more than 2000 m thick sediments, in coal-bearing swamps environments associated with fluvio-deltaic depositional systems in Late Permian times. The change to hot and arid climate conditions with fluctuating precipitation, related to red bed environments, occurred during the early Triassic in Mozambique. The Middle Triassic hiatus event, identified in Mozambique (Fernandes et al., 2015), can be correlated across the Karoo rift basins of East Africa (Tanzania, Kenya, Zambia, Mozambique, Madagascar), representing an important tectonic event in the development of these Karoo basins. This tectonic event observed in the East African/Madagascan region is characterized by a general uplift and erosion of the Karoo basins, and was followed by another major rifting event in the Late Triassic. This unique tectonic event set it apart from all other Karooage basins of Africa, in particular from the Main Karoo Basin of South Africa, which depositional history is related to the development of a foreland basin formed by the tectonic load of the Cape Fold Belt. The differences in the tectonic style between the Main Karoo Basin and the East Africa rift basins should be emphasized and could have affected the FOs of the key-taxa hampering the establishment of robust correlation schemes across central Gondwana.

\section{Conclusions}

The main results from this study are summarized below:

- in N'Condédzi sub-basin of MMCB, the Matinde Formation succession is dated late Permian (Lopingian) and the Cádzi Formation is dated Lower Triassic to Upper Triassic. No Middle Triassic rocks were recognized; therefore, the contact between the Lower and the Upper Triassic sedimentary rocks could correspond to a major hiatus;

- the Lopingian age is defined in detail based on three main palyno-assemblages (Assemblage L1 based in FO of Guttulapollenites pollen; Assemblage L2 is marked by the FO of Thymospora pseudothiessenii and Assemblage L3 is defined by the FO of Osmundacidites senectus);

- Lopingian palyno-assemblages recovered in N'Condédzi subbasin correlate fully with the palyno-assemblages recovered in the Muarádzi sub-basin of the MMCB;

- palynomorphs of Triassic age were identified for the first time in the Mozambican Karoo basins. This study allowed the identification of three new Triassic assemblages: Assemblage T1 is defined by the FO of Densoisporites nejburgii of Induan age, Assemblage T2 is marked by the FO of Platysaccus queenslandi and could be assigned to the Olenekian age, and Assemblage T3 is defined by the FO of Samaropollenites speciosus and Enzonalasporites vigens, indicating a Carnian age;

- the recent biostratigraphic data obtained constrains the age of the Karoo Supergroup formations of Mozambique, and it is a major contribute to a better understanding of the palaeoecological and palaeoclimatic evolution of the basin;

- the absence of Middle Triassic sedimentary rocks, identified by the study of the palynological record, correlates well with a Middle Triassic episode of uplift and erosion described by Fernandes et al. (2015) for the MMCB in the Muarádzi sub-basin. Moreover, the presence of Permian reworked palynomorphs in upper Triassic sedimentary rocks supports this Middle Triassic tectonic event;

- this study increases the knowledge of the palaeogeographic position of the Mozambique basins within the Gondwana supercontinent.

\section{Disclosure of interest}

The authors declare that they have no competing interest.

\section{Acknowledgments}

The research was supported by the project PALEOCLIMOZ (PTDC/CTA-GEO/30082/2017). The authors would like to thank the Managers of Coal India Africana, Limitada and Gondwana Empreendimentos e Consultorias, Limitada, for borehole access and complementary information. Francesca Galasso acknowledges the University of Perugia for the opportunity to participate in the program Erasmus + Traineeship, funded by the European Commission. LNEG's technician Irene Sousa is acknowledged for laboratory support and sample preparation. Editor and the reviewers A. Gotz and M. di Pasquo are gratefully acknowledge for valuable comments that improved the manuscript.

\section{Appendix A. Appendix A}

\section{List of Taxa}

List of spore-pollen species identified in the studied sections of the N'Condédzi sub-basin.

Anapiculatisporites sp.

Anapiculatisporites spiniger (Leschik) Reinhardt/Carnisporites anteriscus Morbey, 1975

Aratrisporites sp.

Baculatisporites bharadwaji Hart, 1963

Baculatisporites sp.

Brevitriletes cornutus (Balme and Hennelly) Backhouse, 1991

Brevitriletes sp.

Calamospora landiana Balme, 1970

Calamospora rugosa (Ibrahim) Schopf, Wilson and Bentall, 1944

Calamospora sp.

cf. Dictyophyllidites sp.

Convolutispora sp.

Cyclogranisporites sp.

Densoisporites complicatus Balme, 1970

Densoisporites nejburgii (Schulz) Balme, 1970

Densoisporites playfordii (Balme) Balme, 1970

Densoisporites spp.

Fabasporites sp.

Granulatisporites sp.

Horriditriletes ramosus (Balme and Hennelly) Bharadwaj and Salujha, 1964

Horriditriletes tereteangulatus (Balme and Hennelly) Backhouse, 1991

Horriditriletes sp.

Kraeuselisporites sp.

Laevigatosporites colliensis (Bharadwaj and Hennelly) Venkatachala and Kar, 1968

Laevigatosporites vulgaris (Ibrahim) Ibrahim, 1933

Laevigatosporites spp.

Leiotriletes adnatus (Kosanke, 1950) Potonié and Kremp, 1955

Leiotriletes directus Balme and Hennelly, 1955

Leiotriletes sp.

Leptolepidites sp.

Limatulasporites limatulus (Playford) Helby and Foster, 1979

Lophotriletes novicus Singh, 1964

Lophotriletes sp.

Lundbladispora brevicula Balme, 1963

Lundbladispora sp.

Microbaculatisporites sp.

Microbaculispora trisina (Balme and Hennelly) Anderson, 1977

Microbaculispora sp. 
Microgranulatisporites sp.

Nevesisporites fossulatus Balme, 1970

Osmundacidites senectus Balme, 1970

Osmundacidites sp.

Playfordiaspora cancellosa (Playford and Dettmann) Maheshwari

and Banerji, 1975

Polypodiisporites sp. sensu Balme, 1970

Polypodiisporites mutabilis Balme, 1970

Procoronaspora spinosa (Anderson) Backhouse, 1991

Punctatisporites spp.

Pyramidosporites sp.

Retusotriletes sp.

Stereisporites sp.

Striatella seebergensis Madler, 1964

Striatella sp.

Taurocusporites sp.

Thymospora pseudothiessenii (Kosanke) Wilson and Venkatachala, 1963

Thymospora sp.

Verrucatisporites sp.

Verrucosisporites andersonii Backhouse, 1988

Verrucosisporites narmianus Balme, 1970

Verrucosisporites sp.

\section{Pollen grains}

Alisporites landianus Balme, 1970

Alisporites ovatus (Balme and Hennelly) Jansonius, 1962

Alisporites parvus de Jersey, 1962

Alisporites plicatus Jizba, 1962

Alisporites potonie (Lakhanpal, Sah and Dube) Somers, 1968

Alisporites sp.

Cannanoropollis sp.

Corisaccites sp.

Cycadopites sp.

Densipollenites sp.

Enzonalasporites vigens Leschik, 1955

Falcisporites stabilis Balme, 1970

Gnetaceaepollenites sinuosus (Balme and Hennelly) Bharadwaj

and Srivastava, 1969

Guttulapollenites hannonicus Goubin, 1965

Hamiapollenites insolitus

Hamiapollenites sp.

Klausipollenites schaubergeri (Potonié and Klaus) Jansonius, 1962

Limitisporites sp.

Lueckisporites virkkiae Potonié and Klaus, 1954

Lueckisporites spp.

Lunatisporites noviaulensis (Leschik) Foster, 1979

Lunatisporites pellucidus (Goubin) Helby, 1972

Lunatisporites sp.

Platysaccus papilionis Potonié and Klaus, 1954

Platysaccus queenslandi de Jersey, 1962

Platysaccus sp.

Protohaploxypinus amplus (Balme and Hennelly) Hart, 1964

Protohaploxypinus goraiensis (Potonié and Lele) Hart, 1964

Protohaploxypinus hartii Foster, 1979

Protohaploxypinus limpidus (Balme and Hennelly) Balme and

Playford, 1967

Protohaploxypinus microcorpus (Schaarschmidt) Clarke, 1965

Protohaploxypinus sp.

Samaropollenites speciosus Goubin, 1965

Striatoabieites multistriatus (Balme and Hennelly 1955) Hart, 1964

Striatoabieites sp.

Striatomonosaccites sp.

Striatopodocarpites cancellatus (Balme and Hennelly) Hart, 1964
Striatopodocarpites fusus (Balme and Hennelly) Potonié, 1956

Striatopodocarpites gondwanensis (Lakhanpal, Sah and Dube)

Hart, 1964

Striatopodocarpites sp.

Tiwarisporites sp.

Triadispora crassa Klaus, 1964

Triadispora sp.

Vittatina costabilis Wilson, 1962

Vittatina fasciolata (Balme and Hennelly) Bharadwaj, 1962

Vittatina scutata (Balme and Hennelly) Bharadwaj, 1962

Vittatina sp.

Weylandites lucifer (Bharadwaj and Salujha) Foster, 1975

Weylandites magmus (Bose and Kar) Backhouse, 1991

\section{Algae and incertae sedis}

Brazilea sp. A in Backhouse, 1991

Chlorophycean algae incertae sedis (sphaeromorph clusters)

Cymatiosphaera gondwanensis (Tiwari) Backhouse, 1991

Mehlisphaeridium sp.

Peltacystia venosa Balme and Segroves, 1966

Reduviasporonites chalastus (Foster) Elsik, 1999

\section{Appendix B. Supplementary data}

Supplementary data associated with this article can be found, in the online version, at https://doi.org/10.1016/j.revmic. 2019.05.001.

\section{References}

Afonso, R.S., 1984. Ambiente geológico dos carvões gonduânicos de Moçambique - uma síntese. In: Lemos de Sousa, M.J. (Ed.), Symposium on Gondwana Coals, Lisbon, 1983. Proceedings and Papers. Comunicações dos Serviços Geológicos de Portugal 70 (2), 205-214.

Artabe, A.E., Morel, E.M., Spalletti, L.A., 2003. Caracterización de las províncias fitogeográficas Triásicas del Gondwana extratropical. Ameghiniana 40, 387-405.

Balme, B.E., 1970. Palynology of Permian and Triassic strata in the Salt Range and Surghar Range, West Pakistan. In: Kummel, B., Teichert, C. (Eds.), Stratigraphic Boundary Problems: Permian and Triassic of West Pakistan. The University Press of Kansas, Lawrence, KS, pp. 305-453.

Backhouse, J., 1991. Permian palynostratigraphy of the Collie Basin, Western Australia. Review of Palaeobotany and Palynology 67, 237-314.

Bicca, M.M., Philipp, R.P., Jelinek, A.R., Ketzer, J.M.M., Scherer, C.M.S., Jamal, D.L., Reis, A.D., 2017. Permian-early Triassic tectonic and stratigraphy of the Karoo Supergroup in Northwestern Mozambique. Journal of African Earth Sciences $130,8-27$.

Bicca, M.M., Jelinek, A.R., Philipp, R.P., Lana, C.C., Alkmim, A.R., 2018. PrecambrianCambrian provenance of Matinde Formation, Karoo Supergroup, northwestern Mozambique, constrained from detrital zircon U-Pb age and Lu-Hf isotope data. Journal of African Earth Sciences 138, 42-57.

Buratti, N., Cirilli, S., 2007. Microfloristic provincialism in the Upper Triassic Circum - Mediterranean area and palaeogeographic implication. Geobios 40, $133-142$.

Carvalho, L.H.B., 1977. Formações vulcânicas de Carinde, Tete-Moçambique. Instituto Superior Técnico, Lisboa (Unpublished Ph.D. Thesis).

Catuneanu, O., Wopfner, H., Eriksson, P.G., Cairncross, B., Rubidge, B.S., Smith, R.M.H., Hancox, P.J., 2005. The Karoo basins of south-central Africa. Journal of African Earth Sciences 43, 211-253.

Césari, S.N., Colombi, C.E., 2013. A new Late Triassic phytogeographical scenario in westernmost Gondwana. Nature Communications 4 (1889), 1-6.

Césari, S.N., Colombi, C.E., 2016. Palynology of Late Triassic Ischigualasto Formation, Argentina: paleoecological and paleogeographic implications. Palaeogeography, Palaeoclimatology, Palaeoecology 449, 365-384.

Cirilli, S., 2010. Upper Triassic lowermost Jurassic palynology and palynostratigraphy: a review. Geological Society of America Bulletin 334, 285-314

Cirilli, S., Pirini, C., Ponton, M., Radrizzani, S., 1998. Stratigraphical and palaeoenvironmental analysis of the Permian-Triassic transition in the Badia Valley (Southern Alps, Italy). Palaeogeography, Palaeoclimatology, Palaeoecology 138 (1-4), 85-113.

Cirilli, S., Buratti, N., Gugliotti, L., Frixa, A., 2015. Palynostratigraphy and palynofacies of the Upper Triassic Streppenosa Formation (SE Sicily, Italy) and inference on the main controlling factors in the organic rich shale deposition. Review of palaeobotany and palynology 218, 67-79.

Cirilli, S., Panfili, G., Buratti, N., Frixa, A., 2018. Paleoenvironmental reconstruction by means of palynofacies and lithofacies analyses: an example from the Upper 
Triassic subsurface succession of the Hyblean Plateau Petroleum System (SE Sicily, Italy). Review of Palaeobotany and Palynology 253, 70-87.

di Pasquo, M., Anderson, H., Isaacson, P., 2017. Record of a Pennsylvanian-Cisuralian marine transgression, southern Bolivia: a short-lived event in western Gondwana? Palaeogeography, Palaeoclimatology, Palaeoecology 485, 30-45.

Dolby, J.H., Balme, B.E., 1976. Triassic palynology of the Carnarvon Basin, Western Australia. Review of Palaeobotany and Palynology 22, 105-168.

Duncan, R.A., Hooper, P.R., Rehacek, J., Marsh, J.S., Duncan, A.R., 1997. The timing and duration of the Karoo igneous event, southern Gondwana. Journal of Geophysical Research, Solid Earth (1978 to 2012) 102 (B8), 18127-18138.

Falcon, R.M.S., 1975. Palynostratigraphy of the Lower Karroo sequence in the central Sebungwe District, Mid-Zambezi Basin, Rhodesia. Palaeontologica Africana 18, $1-29$.

Falcon, R.M.S., Pinheiro, H., Sheperd, P., 1984. The palynobiostratigraphy of the major coal seams in the Witbank Basin with lithostratigraphic, chronostratigraphic and palaeoclimatic implications. Comunicações dos Serviços Geológicos de Portugal 70, 215-243

Fernandes, P., Cogné, N., Chew, D.M., Rodriges, B., Jorge, R.C.S., Marques, J., Jamal, D., Vasconcelos, L., 2015. The thermal history of Karoo Moatize-Minjova Basin, Tete Province, Mozambique: an integrated vitrinite reflectance and apatite fission track thermochronology study. Journal of African Earth Sciences 112, 55-72

Foster, C.B., Balme, B.E., Helby, R., 1994. First record of tethyan palynomorphs from the Late Triassic of East Antarctica. Journal of Australian Geology and Geophysics $15,239-246$.

Foster, C.B., Logan, G.A., Summons, R.E., 1998. The Permian-Triassic boundary in Australia: where is it and how is it expressed? Proceedings of the Royal Society of Victoria 110, 247-266.

Galasso, F., Fernandes, P., Montesi, G., Marques, J., Spina, A., Pereira, Z., 2019. Thermal history and basin evolution of the Moatize-Minjova Coal Basin (N'Condédzi subbasin, Mozambique) constrained by organic maturation levels. Journal of African Earth Sciences 153,219-238, http://dx.doi.org/10.1016/j.jafrearsci.2019.02.020.

Götz, A., Hancox, P.J., Lloyd, A., 2017. Permian climate change recorded in palynomorph assemblages of Mozambique (Moatize Basin, eastern Tete Province). Acta Paleobotanica 57 (1), 3-11.

Götz, A.E., Hancox, P.J., Lloyd, A., 2018. Southwestern Gondwana's Permian climate amelioration recorded in coal-bearing deposits of the Moatize sub-basin (Mozambique). Palaeoworld, http://dx.doi.org/10.1016/j.palwor.2018.08.004 (in press, corrected proof).

Gobin, N., 1965. Description et répartition des principaux pollenites Permiens, Triasique et Jurassiques des sondages du bassin de Morondava (Madagascar). Revue de l'Institut Français du Pétrole 20 (10), 1415-1461.

Grantham, G.H., Macey, P.H., Ingram, B.A., Roberts, M.P., Armstrong, R.A., Hokada, T., Shiraishi, K., Jackson, C., Bisnath, A., Manhiça, V., 2008. Terrane correlation between Antarctica, Mozambique and Sri Lanka; comparisons of geochronology, lithology, structure and metamorphism and possible implications for the geology of southern Africa and Antarctica. In: Satish-Kumar, M., Motoyoshi, Y., Osanoi, Y., Hiroi, Y., Shiraishi, K. (Eds.), Geodynamic Evolution of East Antarctica: a Key to the East-West Gondwana Connection, 308. Geological Society, London, Special Publication, pp. 91-119.

GTK Consortium, 2006. Map Explanation. Volume 2: Sheets 1631-1934 Geology of Sheets, Mecumbura, Chioco, Tete, Tambara, Guro, Chemba, Manica, Catandica, Gorongosa, Rotanda, Chimoio and Beira, Mozambique. Ministério dos Recursos Minerais, Direcção Nacional de Geologia, Maputo.

Hankel, O., 1987. Lithostratigraphic subdivision of the Karoo rocks of the Luwegu Basin (Tanzania) and their biostratigraphic classification based on microfloras, macrofloras, fossil woods and vertebrates. Geologische Rundschau 76, 539-565.

Hankel, O., 1991. Early Triassic plant microfossilis from the Kavee Quarry section of the Lower Mariakani Formation, Kenya. Review of Palaeobotany and Palynology $68,127-145$

Hankel, O., 1992. Late Permian to Early Triassic microfloral assemblages from the Majiya Chumvi Formation, Kenya. Review of Palaeobotany and Palynology 72, 129-147.

Hankel, O., 1993. Early Triassic plant microfossils from Sakamena sediments of the Majunga Basin, Madagascar. Review of Palaeobotany and Palynology 77. 213-233.

Hermann, E., Hochuli, P.A., Bucher, H., Roohi, G., 2012. Uppermost Permian to Middle Triassic palynology of the Salt Range and Surghar Range, Pakistan. Review of Palaeobotany and Palynology 169, 61-95.

Hermann, E., Bucher, H., 2015. Palynostratigraphy at the Permian-Triassic boundary of the Amb section, Salt Range, Pakistan. Palynology 39 (1), 1-18.

Hochuli, P.A., Vigran, J.O., Hermann, E., Bucher, H., 2010. Multiple climatic changes around the Permian-Triassic boundary event revealed by an expanded palynological record from mid-Norway. Geological Society of America Bulletin 122, 884-896.

Jamal, D.L., (Unpublished Ph.D. thesis) 2005. Crustal Studies Across Selected Geotransects in NE Mozambique: Differentiating Between Mozambican (Kibaran) and Pan-African Events, with Implications for Gondwana Studies. University of Cape Town, Cape Town, South Africa.

Jha, N., Srivastava, S.C., 1996. Ninth International Gondwana Symposium, Hyderabad. Geological Survey of India Oxford and IBH Publishing Co., New Delhi-Calcutta, pp. 355-368.

Jha, N., 2006. Permian palynology from India and Africa: a phytogeographical paradigm. Journal of the Palaeontological Society of India 51, 43-55.
Jha, N., Aggarwal, N., Mishra, S., 2018. A review of the palynostratigraphy of Gondwana sediments from the Godavari Graben, India: global comparison and correlation of the Permian-Triassic palynoflora. Journal of Asian Earth Sciences $163,1-21$.

Lächelt, S., 2004. Geology and Mineral Resources of Mozambique. Direcção Naciona de Geologia, Maputo.

Lakshminarayana, G., 2015. Geology of Barcode type coking coal seams, Mecondezi sub-basin, Moatize Coalfield, Mozambique. International Journal of Coal Geology $146,1-13$.

Lindström, S., McLoughlin, S., 2007. Synchronous palynofloristic extinction and recovery after the end-Permian event in the Prince Charles Mountains, Antarctica: implications for palynofloristic turnover across Gondwana. Review of Palaeobotany and Palynology 145, 89-122.

Lopes, G., Pereira, Z., Fernandes, P., Marques, J., 2014. Datação Palinológica dos Sedimentos. Glaciogénicos da Formação (Tilítica) de Vúzi, sondagem ETA 65 Bacia Carbonífera de Moatize-Minjova, Moçambique-Resultados Preliminares. In: Actas do IX Congresso Nacional de Geologia $2^{\circ}$ Congresso de Geologia dos Países de Língua Portuguesa, Porto, Portugal, p. 7.

Msaky, E., Srivastava, V., 1997. Lower Karoo (K5-K6) Palynological assemblage from Tanzania. In: Abstract 3rd Symposium of African Palynology. Johannesburg South Africa, p. 31.

Norconsult Consortium, 2007. Notícia Explicativa: Folhas 1039 Muidine, 1040 Palma, 1134 Ponta Messuli, 1135 Lupilichi, 1136 Milepa, 1137 Macalange, 1138, Negomano, 1139 Mueda, 1140 Mocímboa da Praia, 1234 Metangula, 1235 Macaloge- Chiconono, 1236 Mavago, 1237 Mecula, 1238 Xixano, 1239 Meluco, 1240 Quissanga-Pemba, 1334 Meponda, 1335 Lichinga, 1336 Majune, 1337 Marrupa, 1338 Namuno, 1339 Montepuez, 1340 Mecúfi, 1435 Mandimba, 1436 Cuamba, 1437 Malema, 1438 Ribáuè-Mecubúri, 1535 Insaca, 1536 Gúruè, 1635 Milange e 1636 Lugela-Mocuba, Moçambique. Direcção Nacional de Geologia, Ministério dos Recursos Minerais, Maputo.

Nyambe, I.A., Utting, J., 1997. Stratigraphy and palynostratigraphy, Karoo Supergroup (Permian and Triassic), mid-Zambesi Valley, southern Zambia. Journal of African Earth Sciences 24, 563-583.

Paulino, F., Vasconcelos, L., Marques, J., 2010. Estratigrafia do Karoo em Moçambique. Novas Unidades Karoo Stratigraphy in Mozambique. New Units. In: X Congresso de Geoquímica dos Países de Língua Portuguesa XVI Semana de Geoquímica.

Pereira, Z., Lopes, G., Fernandes, P., Marques, J., 2014. Estudo palinoestratigráfico da sondagem ETA 72 do Karoo Inferior da Bacia de Moatize, Moçambique - Resultados Preliminares. In: Actas do IX Congresso Nacional de Geologia/2 ${ }^{\circ}$ Congresso de Geologia dos Países de Língua Portuguesa, Porto, Portugal.

Pereira, Z., Fernandes, P., Lopes, G., Marques, J., Vasconcelos, L., 2016. The Permian-Triassic transition in the Moatize-Minjova Basin, Karoo Supergroup, Mozambique: a Palynological Perspective. Review of Palaeobotany and Palynology $226,1-19$.

Pereira, Z., Fernandes, P., Lopes, G., Marques, J., Vaz, M., Costa, M., Correia, J., Castro, L., Galasso, F., 2019. Palynology of the Muarádzi sub-basin, Moatize-Minjova Coal Basin, Karoo Supergroup, Mozambique. Review of Palaeobotany and Palynology (submt.).

Pinna, P., Jourde, G., Calvez, J.Y., Mroz, J.P., Marques, J.M., 1993. The Mozambique Belt in northern Mozambique: Neoproterozoic (1100-850 Ma) crustal growth and tectogenesis, and superimposed Pan-African (800-550 Ma) tectonism. Precambrian Research 62, 1-59.

Prasad, B., 1997. Palynology of the subsurface Triassic sediments of KrishnaGodavari Basin. India. Palaeontographica B 242, 91-125.

Retallack, G.J., 1977. Reconstructing Triassic vegetation of eastern Australia: a new approach for the biostratigraphy of Gondwanaland. Alcheringa 1, 247-278.

Riboulleau, A., Spina, A., Vecoli, M., Riquier, L., Quijada, M., Tribovillard, N., Averbuch, O., 2018. Organic matter deposition in the Ghadames Basin (Libya) during the Late Devonian - A multidisciplinary approach. Palaeogeography, Palaeoclimatology, Palaeoecology 497, 37-51.

Riding, J., Warny, S. (Eds.), 2008. Palynological Techniques by CA Brown., second ed. AASP Foundation, The Palynological Society, Dallas, USA

Spina, A., Cirilli, S., Utting, J., Jansonius, J., 2015. Palynology of the Permian and Triassic of the Tesero and Bulla sections (Western Dolomites, Italy) and consideration about the enigmatic species Reduviasporonites chalastus. Review of Palaeobotany and Palynology 218, 3-14.

Spina, A., Di Michele, A., Marcogiuseppe, A., Riboulleau, A., Clayton, G., Riquier, L., Vecoli, M., Sassi, P., Rettori, R., Cirilli, S., Servais, T., 2018a. Application of Palynomorph Darkness Index (PDI) to assess the thermal maturity of palynomorphs: a case study from North Africa. International Journal of Coal Geology 188, 64-78.

Spina, A., Stephenson, M.H., Cirilli, S., Aria-Nasab, M., Rettori, R., 2018b. Palynostratigraphy of the Permian Faraghan Formation in the Zagros Basin, southern Iran. Rivista Italiana di Paleontologia e Stratigrafia 124 (3), 573-595.

Srivastava, S.C., Jha, N., 1990. Permian-Triassic palynofloral transition in Godavari Graben, Andhra Pradesh. Palaeobotanist 38, 92-97.

Steiner, M.B., Eshet, Y., Rampino, M.R., Schwindt, D.M., 2003. Fungal abundance spike and the Permian-Triassic boundary in the Karoo Supergroup (South Africa). Palaeogeography, Palaeoclimatology, Palaeoecology 194, 405-414.

Tripathi, A., Raychowdhuri, A.K., 2005. Triassic palynoflora from the MahuliMahersop Area, Singrauli Coalfield (Southern Extension), Sarguja District, Chhattisgarh, India. Journal of the Palaeontological Society of India 50, 77-99.

Vasconcelos, L., 2013. Coal deposits in Mozambique an overview. In: Presentation at FFF Mozambique coal conference, October 2013 - Johannesburg, South Africa.

Viola, G., Henderson, I.H.C., Bingen, B., Thomas, R.J., Smethurst, M.A., Azevedo, S. 2008. Growth and collapse of a deeply eroded orogen: insights from structural 
and geochronological constraints on the Pan-African evolution of NE Mozambique. Tectonics 27, TC5009.

Ward, P.D., Montgomery, D.R., Smith, R., 2000. Altered river morphology in South Africa related to the Permian-Triassic extinction. Science 289, 1740-1743.

Wood, G.D., Gabriel, A.M., Lawson, J.C., 1996. Palynological techniques-processing and microscopy. In: Jansonius, J., Mcgregor, D.C. (Eds.), Palynology: Principles an Applications, Vol. 1. American Association of Stratigraphic Palynologists Foundation, Salt Lake City, Utah, USA, pp. 29-50.
Wopfner, H., 1999. The Early Permian deglaciation event between East Africa and northwestern Australia. Journal of African Earth Sciences 29 (1), 77-90.

Wright, R.P., Askin, R.A., 1987. The Permian-Triassic boundary in the Southern Morondava Basin of Madagascar as defined by plant microfossils. In: McKenzie, G.D. (Ed.), Gondwana Six: Stratigraphy, Sedimentology, and Palaeontology. Geophysical Monograph, Vol. 41. American Geophysical Union, Washington, DC, pp. 175-197. 